BOGUMIŁ SZADY* - LUBLIN

\title{
WIZYTACJE DIECEZJI CHEŁMSKIEJ - WIZYTACJA BISKUPA KRZYSZTOFA JANA SZEMBEKA (1714-1718)
}

Seria protokołów wizytacyjnych biskupa Krzysztofa Jana Szembeka z lat 1714-1718 należy do najcenniejszych, a jednocześnie najtrudniejszych z punktu widzenia analizy historycznej. Zostały one zebrane w dwóch obszernych woluminach przechowywanych w Archiwum Archidiecezjalnym w Lublinie (Rep. 60, sygn. 152 i 153). Trudno sobie wyobrazić podejmowanie zagadnień związanych z dziejami diecezji chełmskiej bez sięgania do tych tomów, przede wszystkim ze względu na olbrzymią liczbę wpisów wcześniejszych dokumentów. Należy pamiętać, że duża część oryginalnych dokumentów z XIV-XVI wieku spłonęła w pożarze 6 kwietnia 1597 roku$^{1}$.

Biskup Krzysztof Jan Szembek, brat prymasa Stanisława, objął rządy w diecezji chełmskiej w 1713 roku. Główny wysiłek w czasie krótkich rządów w diecezji (do 1719 r.) położył na zwizytowanie kościołów oraz zorganizowanie synodu diecezjalnego, który odbył się w 1717 roku. Odpis postanowień tego synodu znalazł się w ostatniej części drugiego tomu wizytacji² .

Formularz i układ protokołów wizytacyjnych nie wyłania jednolitego schematu ich przeprowadzenia. Mimo zamieszczenia na początku wizytacji złożonej z 24 punktów „Ordo pro visitatione ecclesiarum dioecesis Chełmensis anno Domini 1714 praescriptus". Ważną i obszerną część stanowi wizytacja katedry w Krasnymstawie. Przy jej okazji została oblatowana większość dokumentów ważnych dla biskupstwa oraz kolegiów kleru katedralnego (dokument fundacyjny biskupstwa, kapituły katedralnej, kolegium wikariuszy itd.).

Dzięki datacji zamieszczanej często przy dekretach reformacyjnych można próbować odtworzyć itinerarium biskupa Szembeka. Należy przy tym pamiętać,

${ }^{*}$ Bogumił Szady - dr historii, adiunkt w Instytucie Historii Wydziału Nauk Humanistycznych KUL.

${ }^{1}$ L. Bieńkowski, Działalność organizacyjna biskupa Jana Biskupca $w$ diecezji chetmskiej (1417-1452), „Roczniki Humanistyczne”, 7 (1958) z. 2, s. 255.

${ }^{2}$ Encyklopedia Kościelna, red. M. Nowodworski, t. 27, Warszawa 1904, s. 504-505; P. Nitecki, Biskupi Kościoła w Polsce, Warszawa 1992, s. 201. 
że niemal wszystkie kościoły zwizytował on osobiście. Można wyróżnić cztery fazy wizytacji:

1) od 28 VI do 14 XII $1714 \mathrm{r}$.

2) od 4 V do 18 VII $1715 \mathrm{r}$.

3) od 22 VIII do $25 \times 1715 \mathrm{r}$.

4) od 9 IV do 21 VII $1717 \mathrm{r}$.

Każdy z wymienionych okresów dotyczył innej części biskupstwa. W pierwszym okresie została sprawdzona głównie wschodnia i południowa część diecezji. Biskup poruszał się z północy (m.in. Maciejów, Świerże i Uhrusk) w kierunku południowym i wschodnim (Sokal, Tartaków, Stojanów, Stanin), a następnie na zachód (Dub, Rzeplin, Żerniki). W drugiej fazie wizytacja objęła kilka parafii dekanatów Turobin i Zamość, a więc zachodnią część diecezji. W drugiej połowie 1715 roku biskup przeniósł się na wschód, żeby odwiedzić głównie parafie dekanatu Luboml. W 1717 roku wizytacja objęła bełską, tj. południową, część diecezji chełmskiej (dekanaty Potylicz, Bełz i Grabowiec).

Nie wszystkie kościoły biskup odwiedził osobiście. Do kilku, położonych głównie na krańcach diecezji delegował duchownych diecezjalnych, m.in. kościół w Krasnobrodzie odwiedził Bartłomiej Jan Kurkiewicz, pleban uhnowski, w Biłgoraju - Aleksander Stępkowski, pleban w Płonce. Kościół katedralny w końcu 1718 roku opisał z polecenia biskupa Szembeka Michał Piechowski, kanonik katedralny, prepozyt wiślicki, kanonik skalbmierski i pleban w Kumowie, audytor biskupa chełmskiego. Ponadto kontrolę zaleceń biskupich dla parafii Maciejów (28 VI 1714), Opalin (20 IX 1715), Luboml (23 IX 1715), Ratno $(1 \times 1715)$, Przewały $(7 \times 1715)$, Korytnica $(9 \times 1715)$, Dubienka $(11 \times 1715)$ przeprowadził z polecenia biskupa dziekan foralny lubomelski w marcu i kwietniu 1717 roku.

Poniższe repertorium zostało opracowane zgodnie z metodą omówioną w części dotyczącej XVII wieku³. Pojawiło się jedynie kilka nowych skrótów związanych zwłaszcza z regestami dokumentów, których nie było w wizytacjach XVIIwiecznych:

dek. ref. - dekret reformacyjny;

pol. - dokument w języku polskim (w wizytacji dominuje język łaciński);

dot. - dotyczy (przy ogólnym omawianiu treści dokumentów);

wyd. - wydanie;

trans. - transumpt;

potw. - potwierdzenie;

Ze względów praktycznych zrezygnowano ze sporządzania regestów wszystkich dokumentów. Zostały zamieszczone regesty dokumentów wydanych przed rokiem 1600 (tj. przed pożarem archiwum biskupiego w Krasnymstawie). Do wyjątków należą dokumenty fundacyjne oraz erekcyjne beneficjów, gdyż regesty tychże ze względu na ich znaczenie zostały uwzględnione także jeżeli powstały w XVII i XVIII w. Jeżeli wizytacja podaje pełne teksty dokumentów, zostały $\mathrm{w}$ repertorium zamieszczone ich regesty, natomiast w nawiasie kwadratowym

${ }^{3}$ B. Szady, Wizytacje diecezji chetmskiej - XVII wiek, „Archiwa Biblioteki i Muzea Kościelne”, $82(2004)$ s. $269-288$. 
umieszczono jedynie informacje o dacie i miejscu oraz wystawcy potwierdzenia. Pominięte przy tym zostały, o ile nie zawierały oblatowanych dokumentów, wypisy z akt biskupów i oficjalatu - podano jedynie ich datę. Dla pewnego ułatwienia poruszania się po repertorium pogrubiono nazwy miejscowości, w których znajdowały się sprawdzane przez biskupa lub jego wysłanników świątynie. Ponieważ nagłówki w wizytacji informujące o dekanatach nie odpowiadają zawartości treściowej księgi zrezygnowano $\mathrm{z}$ ich zamieszczania, aby nie wprowadzały w błąd czytelnika. 


\section{Archiwum Archidiecezjalne w Lublinie Rep60 A152 - ABMK 2369}

I. Acta visitationis generalis omnium ecclesiarum dioecesis Chełmensis, quam ipsemet illustrissimus excellentissimus et reverendissimus dominus dominus Christophorus in Słupow Szembek Dei et Apostolicae Sedis gratia episcopus Chełmensis, praepositus generalis Miechoviensis in sua propria persona anno Domini 1714 die 1ma mensis septembris ab ecclesia parochiali Gorzkoviensi inchoavit et tandem anno Domini 1717 in ecclesia praepositurali Skierbieszoviensi feliciter terminavit diebus prima et secunda mensis iulii.

II. Wizytacja zewnętrzna. Czystopis.

Format: $33,5 \times 21 \mathrm{~cm}$

k. $1010+$ knlb: 1-5 (na początku księgi), $3^{\mathrm{a}}, 233^{\mathrm{a}}-233^{\mathrm{d}}, 238^{\mathrm{a}}-239^{\mathrm{e}}, 427^{\mathrm{a}}-428^{\mathrm{a}}$, $509^{\mathrm{a}}, 513^{\mathrm{a}}, 540^{\mathrm{a}}, 621^{\mathrm{a}}-621^{\mathrm{b}}, 1000^{\mathrm{a}}-1000^{\mathrm{c}}$; brak k. 224-227, 313-314, 572, 610-615, 626, 667, 701-704, 706-711, 973, 989-997; k. niezapisane: 3, 30, 154-156, 203, 228-229, 237, 239 e 270-271, 315, 415-417, 432-434, 438, 493-498, 515, 573, $621,627,649,666,705,757,854-855$; pomyłki w numeracji kart: po k. 90 jest k. 100 , powtórzony numer k. 238-239, po k. 289 jest k. 300, k. 979 wklejona po k. 367 , powtórzony numer k. 428a , k. 655-656 wklejone po k. 635, k. 975-978 wklejone odwrotnie po k. 972, k. 998-1002 wklejone po k. 1007, k. 1008 wklejona po k. 987, k. 1009-1010 wklejone po k. 1004.

\begin{tabular}{|l|l|}
\hline knlb. 1-2 & [spis treści] \\
\hline knlb. 3-4 & [drukowany kwestionariusz wizytacji] \\
\hline knlb. 5 & [strona tytułowa] \\
\hline k. 1-2v & $\begin{array}{l}\text { Ordo pro visitatione ecclesiarum dioecesis Chełmensis anno Domini 1714 prae- } \\
\text { scriptus [instrukcja wizytacyjna złożona z 24 punktów] }\end{array}$ \\
\hline k. 3 -3 $^{\text {av }}$ & $\begin{array}{l}\text { Dub, 15 XI 1714 } \\
\text { Reintimatio visitationis ecclesiarum decanatuum restantium [list biskupa chełm- } \\
\text { skiego, Krzysztofa Szmbeka, nakazujący duchowieństwu lepsze przygotowanie } \\
\text { do wizytacji] }\end{array}$ \\
\hline k. 4-4v & $\begin{array}{l}\text { [list opisujący rozpoczęcie wizytacji w Krasnymstawie 1 } \\
\text { pisarza Tomasza Andrzeja Koluszkowskiego] }\end{array}$ \\
\hline k. 5-29 & $\begin{array}{l}\text { Nowy Krasnystaw [dot. biskupstwa i kościoła katedralnego] } \\
\text { Władysław Jagiełło funduje biskupstwo chełmskie [wyd. W. Abraham, Akt funda- } \\
\text { cyjny króla Władystawa Jagiełty dla biskupstwa chełmskiego, „Kwartalnik Histo- } \\
\text { ryczny”, 32 (1918), s. 473-478] }\end{array}$ \\
\hline k. 5-7v & $\begin{array}{l}\text { Kraków, 26 VI 1490 } \\
\text { Kazimierz Jagiellończyk przenosi stolicę i katedrę biskupią z Chełma do Krasne- } \\
\text { gostawu [wyd. B. Kumor, Przeniesienie stolicy biskupiej z Chełma do Krasnego- } \\
\text { stawu (1490), ABMK, 49 (1984), s. 378-380] }\end{array}$ \\
\hline k. 7v-8v & $\begin{array}{l}\text { Radom, 5 IX 1491 } \\
\text { Kazimierz Jagiellończyk przekazuje biskupowi chełmskiemu prawo patronatu ka- } \\
\text { nonikatu kaznodziei w kapitule katedralnej }\end{array}$ \\
\hline k. 8v-9
\end{tabular}




\begin{tabular}{|c|c|}
\hline k. $9-9 \mathrm{v}$ & $\begin{array}{l}\text { Knyszyn, } 16 \text { I } 1554 \\
\text { Zygmunt August przekazuje biskupom chełmskim grunt w pobliżu Krasnegosta- } \\
\text { wu pod zabudowania folwarczne }\end{array}$ \\
\hline k. $10-13 v$ & $\begin{array}{l}\text { dok. } 1659 \text { [pol.], 1695, } 1718 \text { [dot. uposażenia biskupstwa i kapituły oraz wizytacji } \\
\text { kościołów unickich] }\end{array}$ \\
\hline k. $14-15$ & $\begin{array}{l}\text { Status praesens bonorum mensae episcopalis Chełmensis circa finem anni } 1718 \\
\text { conscriptus [opis dóbr stołowych biskupstwa chełmskiego: Skierbieszów, Ku- } \\
\text { mów, Pawłów, Sawin] }\end{array}$ \\
\hline k. $15 \mathrm{v}-16 \mathrm{v}$ & Inscriptiones variae [teksty inskrypcji w kościele katedralnym] \\
\hline k. $17-18$ & $\begin{array}{l}\text { Inwentarz srebra kościoła katedralnego krasnostawskiego spisany w roku pań- } \\
\text { skim } 1714 \text {, dnia } 3 \text { miesiąca października [pol.] }\end{array}$ \\
\hline k. $18 \mathrm{v}-22$ & $\begin{array}{l}\text { Inwentarz apparatów kościoła katedralnego krasnostawskiego spisany w roku } \\
\text { pańskim } 1714 \text {, dnia } 3 \text { miesiąca października [pol.] }\end{array}$ \\
\hline k. $22-25 \mathrm{v}$ & $\begin{array}{l}\text { Inwentarz argenteryi, apparatów et totius sacrae supellectilis kościoła katedralne- } \\
\text { go krasnostawskiego podczas generalney kapituły Divisionis Sanctorum Aposto- } \\
\text { lorum post visitationem generalem spisany roku pańskiego } 1718 \text { [pol.] }\end{array}$ \\
\hline k. 26-29 & $\begin{array}{l}\text { Fundatio patres Societatis Iesu Crasnostaviae [pisma dotyczące powstania kole- } \\
\text { gium jezuitów w Krasnymstawie] }\end{array}$ \\
\hline k. 31-63v & m Krasnystaw [dot. kapituły katedralnej] \\
\hline k. $31 v-33$ & $\begin{array}{l}\text { Borzysławice, } 12 \text { VII } 1429 \\
\text { Władysław Jagiełło potwierdza pierwotną fundację kapituły chełmskiej i ustana- } \\
\text { wia uposażenie jej } 2 \text { prałatów i } 10 \text { kanoników [wyd. P. Kałwa, Przywilej fundacyj- } \\
\text { ny dla kapituły chetmskiej z r. } 1429, \text { „Kwartalnik Historyczny”, } 47 \text { (1933), s. 73- } \\
\text { 77] }\end{array}$ \\
\hline k. $33-34 v$ & $\begin{array}{l}\text { Piotrków, } 14 \text { IX } 1456 \\
\text { Kazimierz Jagiellończyk powiększa uposażenie biskupstwa i kapituły chełmskiej } \\
\text { przez inkorporację kościoła parafialnego w Chełmie wraz z jego uposażeniem }\end{array}$ \\
\hline k. $35 \mathrm{v}-37 \mathrm{v}$ & $\begin{array}{l}\text { Poznań, } 3 \text { VI } 1450 \\
\text { Wyrok polubowny w sprawie o czynsz w wysokości } 100 \text { grzywien z cła chełm- } \\
\text { skiego oraz zajęcie łąk we wsi Parypsy między kapitułą katedralną i starostą } \\
\text { chełmskim }\end{array}$ \\
\hline k. $38-43 v$ & $\begin{array}{l}\text { b. m., } 1 \text { VI } 1556 \\
\text { Jakub Uchański, biskup chełmski, Feliks Snopkowski z Sitna, sędzia chełmski } \\
\text { i inne osoby przeprowadzają w terenie rozgraniczenie dóbr Parypsy, biskupa } \\
\text { chełmskiego od wsi królewskich Nowosiółki, Ochoża, Kołosin, Czułczyce }\end{array}$ \\
\hline k. $38 v-39$ & $\begin{array}{l}\text { Wilno, } 31 \text { III } 1556 \\
\text { Zygmunt August upoważnia Jakuba Uchańskiego, biskupa chełmskiego, Andrze- } \\
\text { ja Bzickiego, kasztelana chełmskiego oraz inne osoby w sprawie rozgraniczenia } \\
\text { dóbr Parypsy, biskupa chełmskiego od wsi królewskich Nowosiółki, Ochoża, Ko- } \\
\text { łosin, Czułczyce }\end{array}$ \\
\hline k. $39-39 v$ & $\begin{array}{l}\text { Wilno, } 31 \text { III } 1556 \\
\text { Zygmunt August upoważnia Gabriela Tarło ze Szczekarzewic, kasztelana radom- } \\
\text { skiego i starostę chełmskiego w sprawie rozgraniczenia dóbr Parypsy, biskupa } \\
\text { chełmskiego od wsi królewskich Nowosiółki, Ochoża, Kołosin, Czułczyce }\end{array}$ \\
\hline
\end{tabular}




\begin{tabular}{|c|c|}
\hline k. $39 v-40$ & $\begin{array}{l}\text { Skierbieszów, } 11 \text { V } 1556 \\
\text { Jakub Uchański, biskup chełmski Andrzej Bzicki, kasztelan chełmski oraz inne } \\
\text { osoby wzywają Gabriela Tarło ze Szczekarzewic, kasztelana radomskiego i staro- } \\
\text { stę chełmskiego do stawienia się w sprawie rozgraniczenia dóbr Parypsy, biskupa } \\
\text { chełmskiego od wsi królewskich Nowosiółki, Ochoża, Kołosin, Czułczyce }\end{array}$ \\
\hline k. $44-45$ & $\begin{array}{l}\text { Drohobycz, } 16 \text { XII } 1392 \\
\text { Władysław Jagiełło uposaża kościół parafialny w Drohobyczu }\end{array}$ \\
\hline k. $46-47$ & $\begin{array}{l}\text { Jedlna, } 8 \text { II } 1418 \\
\text { Władysław Jagiełło przenosi wieś Dobrowlany, należącą do parafii w Drohobyczu } \\
\text { z prawa polskiego na prawo niemieckie }\end{array}$ \\
\hline k. $47-48 v$ & $\begin{array}{l}\text { Radom, } 29 \text { V } 1505 \\
\text { Aleksander Jagiellończyk udziela parafii w Drohobyczu prawo pobierania mosto- } \\
\text { wego w Dobrowlanach }\end{array}$ \\
\hline k. $48 v-50$ & $\begin{array}{l}\text { Krasnystaw, } 15 \text { VIII } 1558 \\
\text { Zygmunt August powiększa uposażenie kapituły katedralnej w Krasnymstawie } \\
\text { przez inkorporację parafii w Drohobyczu }\end{array}$ \\
\hline k. $50 \mathrm{v}-51 \mathrm{v}$ & $\begin{array}{l}\text { Warszawa, } 26 \text { II } 1622 \\
\text { Zygmunt III powiększa uposażenie kapituły katedralnej w Krasnymstawie przez } \\
\text { inkorporację parafii w Grabowcu wraz z jej uposażeniem [wyd. B. Szady, Inkor- } \\
\text { poracja parafii w Grabowcu do chełmskiej kapituty katedralnej w } 1624 \text { roku, w: } \\
\text { Kościót. Społeczeństwo. Kultura. Prace ofiarowane Profesorowi Wiesławowi } \\
\text { Müllerowi z okazji pięćdziesięciolecia pracy naukowej i dydaktycznej, red. J. Drob } \\
\text { i in., Lublin 2004, s. 140-142] }\end{array}$ \\
\hline k. $52-54$ & $\begin{array}{l}\text { Krasnystaw, } 24 \text { V } 1627 \\
\text { Maciej Łubieński, biskup chełmski potwierdza inkorporację parafii w Grabowcu } \\
\text { do kapituły katedralnej w Krasnymstawie oraz określa obowiązki i uposażenie } \\
\text { kapituły i komendariusza [wyd. B. Szady, dz. cyt., s. 142-145] }\end{array}$ \\
\hline k. $54-54 \mathrm{v}$ & dok. 1626 [dot. obsady parafii w Grabowcu] \\
\hline k. $55-58$ & $\begin{array}{l}\text { Rzym, } 15 \text { I } 1710 \\
\text { Papież Klemens XI wyraża zgodę na inkorporację parafii w Hrubieszowie do ka- } \\
\text { pituły katedralnej w Krasnymstawie }\end{array}$ \\
\hline k. $58-60 \mathrm{v}$ & $\begin{array}{l}\text { Krasnystaw, 1 I } 1712 \\
\text { Walenty Czulski, wikariusz in spiritualibus i oficjał generalny chełmski, z polece- } \\
\text { nia papieża Klemensa VII, powiększa uposażenie kapituły katedralnej w Kras- } \\
\text { nymstawie przez inkorporację parafii w Hrubieszowie oraz określa uposażenie } \\
\text { wikariusza wieczystego tej parafii }\end{array}$ \\
\hline k. $60 \mathrm{v}-61$ & dok. 1713 [dot. obsady parafii w Hrubieszowie] \\
\hline k. $61 \mathrm{v}-63 \mathrm{v}$ & $\begin{array}{l}\text { Status modernus reverendissimi capituli praelatorum et canonicorum Chełmen- } \\
\text { sium [omawia dzieje i uposażenie kapituły z końca } 1718 \text { r. oraz zawiera opis pre- } \\
\text { bend i ich obsadę z } 1 \text { I 1715] }\end{array}$ \\
\hline k. 64-161v & m Krasnystaw [dot. wikariuszy, prebendarzy i altarzystów katedralnych] \\
\hline k. $64-66$ & $\begin{array}{l}\text { Index et summarium privilegiorum, iurium, proventuum et censuum vicarios ca- } \\
\text { thedrales Crasnostavienses concernentium [regesty } 40 \text { dokumentów z lat 1419- } \\
1701 \text { ] }\end{array}$ \\
\hline k. $66 \mathrm{v}$ & $\begin{array}{l}\text { Forma iuramenti reverendorum vicariorum cathedralium Crasnostaviensium circa } \\
\text { receptionem ad ecclesiam cathedralem praestari solita [formularz przysięgi] }\end{array}$ \\
\hline
\end{tabular}




\begin{tabular}{|c|c|}
\hline k. $67-151$ & $\begin{array}{l}\text { Compendium privilegiorum, erectionum, iurium ecclesiae cathedralis Cras- } \\
\text { nostaviensis reverendis vicariis cathedralibus Crasnostaviensibus serviens in visi- } \\
\text { tatio generali anno Domini } 1714 \text { [dokumenty dotyczące wikariuszy katedral- } \\
\text { nych] }\end{array}$ \\
\hline k. $67-67 \mathrm{v}$ & $\begin{array}{l}\text { Krasnystaw, } 5 \text { VI } 1418 \text { [powinno być: 1438] } \\
\text { Hryćko Kierdejowicz, starosta krasnostawski, na prośbę plebana Aleksandra oraz } \\
\text { z polecenia króla Władysława Warneńczyka, potwierdza zeznanie mieszczan } \\
\text { krasnostawskich i określa uposażenie parafii w Krasnymstawie [zob. L. Bieńkow- } \\
\text { ski, Działalność organizacyjna biskupa Jana Biskupca w diecezji chetmskiej } \\
\text { (1417-1452), „Roczniki Humanistyczne”, } 7 \text { (1958), z. 2, s. 236-237] }\end{array}$ \\
\hline k. $68-69$ & $\begin{array}{l}\text { Krasnystaw, } 1 \text { VIII } 1419 \text { [dokument prawd. późniejszy] } \\
\text { Jan, biskup chełmski, potwierdza doposażenie kościoła parafialnego w Krasnym- } \\
\text { stawie dokonane przez króla Władysława Jagiełłę na prośbę plebana Jana Slugli- } \\
\text { my [zob. L. Bieńkowski, } d z \text {. cyt., s. 236-237] }\end{array}$ \\
\hline k. $69 \mathrm{v}-70$ & $\begin{array}{l}\text { Krasnystaw, } 15 \times 1451 \\
\text { Hryćko z Pomorzan, wojewoda podolski i starosta trembolewski deklaruje chęć } \\
\text { zamiany gruntów z Aleksandrem, plebanem krasnostawskim [trans. Kazimierza } \\
\text { Jagiellończyka, Kozienice, } 20 \text { XI 1466] }\end{array}$ \\
\hline k. $70-72$ & $\begin{array}{l}\text { Krasnystaw, } 15 \text { XII } 1496 \\
\text { Jan Olbracht uposaża kolegium } 12 \text { wikariuszy przy katedrze krasnostawskiej } \\
\text { i wyraża zgodę na inkorporację do niego dwóch parafii królewskich: Parczew } \\
\text { w diecezji krakowskiej i Płonka w diecezji chełmskiej [trans. Zygmunta I, Kra- } \\
\text { ków, } 25 \text { VI 1523] }\end{array}$ \\
\hline k. $72 v-73 v$ & $\begin{array}{l}\text { Sandomierz, } 5 \text { V } 1460 \\
\text { Kazimierz Jagiellończyk potwierdza i odnawia uposażenie kościoła parafialnego } \\
\text { w Krasnymstawie uczynione przez Władysława Jagiełłę }\end{array}$ \\
\hline k. $73 v-75$ & $\begin{array}{l}\text { Kraków, } 9 \text { I } 1494 \\
\text { Jan Olbracht wyraża zgodę na zakup dwóch domów lub placów w Krasnymstawie } \\
\text { na rezydencję dla wikariuszy katedralnych }\end{array}$ \\
\hline k. $75-78 v$ & $\begin{array}{l}\text { Skierbieszów, } 1 \text { XII } 1525 \\
\text { Biskup Jakub Buczacki inkorporuje do kolegium wikariuszy katedralnych parafie } \\
\text { Krasnystaw i Płonka w diecezji chełmskiej oraz parafię Parczew w diecezji kra- } \\
\text { kowskiej [trans. Zygmunta I, Kraków, 26 I 1527] }\end{array}$ \\
\hline k. $79-80 v$ & $\begin{array}{l}\text { Krasnystaw, } 5 \text { VI } 1418 \text { [powinno być: 1438] } \\
\text { Hryćko Kierdejowicz, starosta krasnostawski, na prośbę plebana Aleksandra oraz } \\
\text { z polecenia króla Władysława Warneńczyka, potwierdza zeznanie mieszczan } \\
\text { krasnostawskich i określa uposażenie parafii w Krasnymstawie [trans. Zygmunta } \\
\text { II, Kraków, } 7 \text { VIII 1553; zob. L. Bieńkowski, dz. cyt., s. 236-237] }\end{array}$ \\
\hline k. $80 v-81 v$ & $\begin{array}{l}\text { Krasnystaw, } 1 \text { VIII } 1419 \text { [dokument prawd. późniejszy] } \\
\text { Jan, biskup chełmski, potwierdza doposażenie kościoła parafialnego w Krasnym- } \\
\text { stawie dokonane przez króla Władysława Jagiełłę na prośbę plebana Jana Slugli- } \\
\text { my [trans. Zygmunta II, Kraków, } 7 \text { VIII 1553; zob. L. Bieńkowski, dz. cyt., s. } \\
\text { 236-237] }\end{array}$ \\
\hline k. $81 \mathrm{v}-85$ & $\begin{array}{l}\text { Ostrzyhom, } 18 \text { IX } 1515 \\
\text { Legat papieski Klemens potwierdza inkorporację do kolegium wikariuszy kate- } \\
\text { dralnych kościołów parafialnych w Krasnymstawie, Parczewie i Płonce }\end{array}$ \\
\hline
\end{tabular}




\begin{tabular}{|c|c|}
\hline k. $85-86 v$ & $\begin{array}{l}\text { Warszawa, } 20 \text { II } 1581 \\
\text { Stefan Batory potwierdzanadaniegruntudla Henryka,,deBuschia”, felczeraw Kras- } \\
\text { nymstawie dokonane przez starostę krasnostawskiego Jana Mniszka i zapisane } \\
\text { w aktach grodzkich krasnostawskich } 13 \text { II } 1579\end{array}$ \\
\hline k. $87-88 v$ & $\begin{array}{l}\text { Krasnystaw, } 5 \text { VI } 1418 \text { [powinno być: 1438] } \\
\text { Hryćko Kierdejowicz, starosta krasnostawski, na prośbę plebana Aleksandra oraz } \\
\text { z polecenia króla Władysława Warneńczyka, potwierdza zeznanie mieszczan } \\
\text { krasnostawskich i określa uposażenie parafii w Krasnymstawie [trans. Zygmunta } \\
\text { III, Warszawa, 22 I 1615; zob. L. Bieńkowski, dz. cyt., s. 236-237] }\end{array}$ \\
\hline k. $88 \mathrm{v}-89$ & $\begin{array}{l}\text { Krasnystaw, } 1 \text { VIII } 1419 \text { [dokument prawd. późniejszy] } \\
\text { Jan, biskup chełmski, potwierdza doposażenie kościoła parafialnego w Krasnym- } \\
\text { stawie dokonane przez króla Władysława Jagiełłę na prośbę plebana Jana Slugli- } \\
\text { my [trans. Zygmunta III, Warszawa, 22 I 1615; zob. L. Bieńkowski, dz. cyt., s. } \\
\text { 236-237] }\end{array}$ \\
\hline k. $89-90$ & $\begin{array}{l}\text { Dobryniów, } 27 \text { VI } 1467 \\
\text { Paweł, biskup chełmski nakazuje wypłacenie zaległej i należnej kolędy ze wsi } \\
\text { Niemienice i Wielobycz plebanowi w Krasnymstawie [trans. Zygmunta III, War- } \\
\text { szawa, 22 I 1615] }\end{array}$ \\
\hline k. $90 \mathrm{v}-102$ & dok. 1613, 1613 [dot. uposażenia wikariuszy katedralnych w Krasnymstawie] \\
\hline k. $102-103 v$ & $\begin{array}{l}\text { Puncta reformationis ex visitatione ecclesiae cathedralis Chełmensis Crasnosta- } \\
\text { viam translatae die } 20 \text { II per illustrissimum et reverendissimum dominum Mat- } \\
\text { hiam Łubienski -- in anno } 1622 \text { circa collegium vicariorum in genere [fragment } \\
\text { dekretu reformacyjnego wizytacji biskupa Łubieńskiego poświęcony wikariu- } \\
\text { szom katedralnym] }\end{array}$ \\
\hline k. $103 \mathrm{v}-104 \mathrm{v}$ & dok. 1661 [dot. uposażenia wikariuszy katedralnych w Krasnymstawie, pol.] \\
\hline k. $105-112$ & $\begin{array}{l}\text { Krasnystaw, } 30 \text { V } 1635 \\
\text { Jakub Sobieski, krajczy koronny powiększa uposażenie wikariuszy katedralnych } \\
\text { sumą } 3200 \text { złotych, z której m.in. ma być płacony czynsz } 130 \text { złotych dla nowo } \\
\text { ufundowanego wikariusza (altarzysty) [trans. Jana Sasina, oficjała generalnego } \\
\text { chełmskiego, Krasnystaw, } 25 \text { VI 1635] }\end{array}$ \\
\hline k. $112-114$ & dok. 1635, 1631 [dot. uposażenia wikariuszy katedralnych w Krasnymstawie] \\
\hline k. $114 \mathrm{v}-116$ & $\begin{array}{l}\text { Skierbieszów, } 10 \text { IV } 1617 \\
\text { Jerzy Zamoyski, biskup chełmski eryguje beneficjum altarzysty Bożego Ciała w ka- } \\
\text { tedrze krasnostawskiej, które jednocześnie włącza do kolegium wikariuszy kate- } \\
\text { dralnych oraz potwierdza w transumpcie dokument fundacyjny Stanisława Grotha, } \\
\text { kanonika gnieźnieńskiego (Krasnystaw, } 3 \text { XI 1607), którym wykonuje on wolę } \\
\text { zmarłego brata, Floriana Grotha, notariusza kancelarii królewskiej }\end{array}$ \\
\hline k. $116 \mathrm{v}-151$ & $\begin{array}{l}\text { dok. 1639, 1640, } 1644 \text { [pol.], 1622, 1654, } 1655 \text { [pol.], 1678, 1678, } 1687 \text { [pol.], } \\
\text { 1683, 1684, } 1687 \text { [pol.], 1687 [pol.], 1687, 1688, 1689, } 1692 \text { [pol.], } 1692 \text { [pol.], } \\
\text { 1690, 1690 [pol.], } 1701 \text { [pol.] [dot. uposażenia wikariuszy katedralnych w Kras- } \\
\text { nymstawie] }\end{array}$ \\
\hline k. $151-153 \mathrm{v}$ & $\begin{array}{l}\text { Proventus reverendorum vicariorum cathedralium Crasnostaviensium -- circa fi- } \\
\text { nem anni } 1718 \text { [opis uposażenia wikariuszy katedralnych] }\end{array}$ \\
\hline k. $157-161 \mathrm{v}$ & $\begin{array}{l}\text { Status praesens ecclesiae cathedralis Crasnostaviensis -- circa finem anno Domini } \\
1718 \text { conscriptus [opis świątyni katedralnej oraz zabudowań duchowieństwa } \\
\text { i szpitali] }\end{array}$ \\
\hline
\end{tabular}




\begin{tabular}{|c|c|}
\hline k. 162-170v & $\begin{array}{l}\text { m Krasnystaw [dot. bractw św. Anny, różańcowego i szkaplerznego w kościele } \\
\text { katedralnym, 1715] }\end{array}$ \\
\hline k. $162-163$ & $\begin{array}{l}\text { Warszawa, } 8 \text { V } 1632 \\
\text { Jerzy Godziszewski, promotor arcybractwa św. Anny w Warszawie eryguje bra- } \\
\text { ctwo św. Anny przy kościele katedralnym w Krasnymstawie [trans. Jana Sasina, } \\
\text { oficjała generalnego chełmskiego, Krasnystaw, } 15 \text { IX 1632] }\end{array}$ \\
\hline k. $163-165$ & $\begin{array}{l}\text { Kumów, } 5 \times 1663 \\
\text { Tomasz Leżeński, biskup chełmski, eryguje beneficjum kapelana św. Anny w koś- } \\
\text { ciele katedralnym w Krasnymstawie i potwierdza w transumpcie dokument fun- } \\
\text { dacyjny Mikołaja Świrskiego, Krasnystaw, } 30 \text { I } 1649\end{array}$ \\
\hline k. $165-170$ & dok. 1669, 1673, 1680, 1669 [dot. uposażenia prebendy św. Anny] \\
\hline k. $170 \mathrm{v}$ & $\begin{array}{l}\text { Confraternitas Sanctissimi Scapularis Beatae Mariae Virginis [krótki opis bractwa } \\
\text { szkaplerznego i różańcowego w Krasnymstawie] }\end{array}$ \\
\hline k. 171-197v & m Krasnystaw [dot. prepozytury i szpitala Św. Ducha w Krasnymstawie, 1715] \\
\hline k. $171-172 v$ & $\begin{array}{l}\text { Krasnystaw, } 18 \text { III } 1560 \\
\text { Mikołaj Bogusz, starosta krasnostawski przekazuje szpitalowi w Krasnymstawie } \\
\text { wójtostwo w Siennicy oraz sumę } 60 \text { florenów, zgodnie z wolą Zygmunta Augusta } \\
\text { (Krasnystaw, } 30 \text { VIII 1558) }\end{array}$ \\
\hline k. $172 \mathrm{v}-173$ & $\begin{array}{l}\text { Chełm, } 17 \text { VI } 1564 \\
\text { Seweryn Repowski, podstarości chełmski oblatuje w aktach grodzkich chełm- } \\
\text { skich decyzję króla z } 1563 \text { roku w sprawie nadania wójtostwa w Siennicy oraz } \\
\text { sumy } 600 \text { [sic!] złotych dla szpitala krasnostawskiego }\end{array}$ \\
\hline k. $173-173 v$ & $\begin{array}{l}\text { [Opisanie dochodów proboszcza i szpitala przez Andrzeja Pieniążka, proboszcza } \\
\text { szpitalnego z } 1619 \text { roku] }\end{array}$ \\
\hline k. $173 \mathrm{v}-174 \mathrm{v}$ & $\begin{array}{l}\text { Krasnystaw, } 30 \text { V } 1614 \\
\text { Andrzej Pieniążek, kanonik i prepozyt szpitalny uposaża beneficjum lektora } \\
\text { w kościele szpitalnym Św. Ducha w Krasnymstawie }\end{array}$ \\
\hline k. $175-197 \mathrm{v}$ & $\begin{array}{l}\text { dok. } 1614 \text { [pol.], } 1614 \text { [pol.], } 1614 \text { [pol.], } 1614 \text { [pol.], 1614, 1616, } 1631 \text { [pol.], } \\
1631 \text { [pol.], } 1633 \text { [pol.], } 1635 \text { [pol.], 1635, } 1665 \text { [pol.], 1673, 1678, } 1693 \text { [pol.], } \\
1696,1701 \text { [pol.], } 1700 \text { [pol.], 1695, } 1696 \text { [pol.], } 1699 \text { [pol.], 1699, } 1697 \text { [pol.], } \\
1699 \text { [dot. uposażenia szpitala i prepozytury św. Ducha w Krasnymstawie] }\end{array}$ \\
\hline k. 198-201 & m Krasnystaw [dot. szpitala św. Łazarza w Krasnymstawie] \\
\hline k. 198-201 & $\begin{array}{l}\text { dok. } 1693,1708 \text { [pol.], } 1709 \text { [pol.], } 1690 \text { [pol.], } 1706 \text { [pol.] [dot. uposażenia szpi- } \\
\text { tala św. Łazarza w Krasnystawie] }\end{array}$ \\
\hline k. $201 v-202 v$ & $\begin{array}{l}\text { m Krasnystaw [dot. kaplicy św. Anny i szpitala oraz prepozytury Św. Ducha w Kras- } \\
\text { nymstawie] }\end{array}$ \\
\hline k. $201 \mathrm{v}-202$ & $\begin{array}{l}\text { Krasnystaw, } 1 \text { VIII } 1419 \\
\text { Jan, biskup chełmski, eryguje beneficjum kapelana św. Anny w Krasnymstawie na } \\
\text { podstawie uposażenia króla Władysława Jagiełły }\end{array}$ \\
\hline k. $202-202$ v & $\begin{array}{l}\text { Łęczyca, } 17 \text { VII } 1465 \\
\text { Kazimierz Jagiellończyk zezwala mieszczanom krasnostawskim na fundację } \\
\text { z dóbr miasta Krasnegostawu szpitala i kaplicy św. Ducha w tym mieście }\end{array}$ \\
\hline k. $202 \mathrm{v}$ & $\begin{array}{l}\text { Skierbieszów, } 28 \text { IX } 1525 \\
\text { Jakub Buczacki, biskup chełmski instytuuje Stanisława Żebrowskiego, wikariu- } \\
\text { sza katedralnego, na beneficjum prepozyta szpitala św. Ducha na podstawie pre- } \\
\text { zenty mieszczan krasnostawskich }\end{array}$ \\
\hline
\end{tabular}




\begin{tabular}{|c|c|}
\hline k. 204-223 & $\begin{array}{l}\text { m Krasnystaw [dekrety reformacyjne dla kapituły katedralnej i niższego ducho- } \\
\text { wieństwa w Krasnymstawie z } 18 \text { XII 1715] }\end{array}$ \\
\hline k. 204-211 & [dekret reformacyjny dla kapituły katedralnej] \\
\hline k. $211 \mathrm{v}-219 \mathrm{v}$ & $\begin{array}{l}\text { [dekret reformacyjny dla wikariuszy, altarzystów i prebendarzy, w tym seniora } \\
\text { wikariuszy katedralnych, promotora bractwa św. Anny] }\end{array}$ \\
\hline k. $219 v-223$ & $\begin{array}{l}\text { [dekret reformacyjny dla wicekustosza katedralnego i prepozyta szpitala św. Du- } \\
\text { cha oraz dla szpitala św. Łazarza w Krasnymstawie] }\end{array}$ \\
\hline k. $230-233$ & dok. XVII w. [dot. uposażenia wikariuszy katedralnych, ok. 1680-1689] \\
\hline k. $233^{\mathrm{a}}-\mathbf{2 3 7 v}$ & $\begin{array}{l}\text { m Hrubieszów [opis historii i stanu parafii oraz kościołów w Czerniczynie i Opa- } \\
\text { linie; wpisy dwóch dokumentów dotyczących uposażenia beneficjum z lat } 1671 \\
\text { i } 1687 \text {, pol.] }\end{array}$ \\
\hline k. 238-239 ${ }^{\mathrm{b}} \mathrm{v}$ & Sitaniec [inwentarz zabudowań i wyposażenia ruchomego z 20 XI 1718, pol.] \\
\hline k. $239^{c}-239^{d} v$ & m Szczebrzeszyn [dekret reformacyjny z 6 V 1715] \\
\hline k. 238-239v & m Dubienka [dok. 1688] \\
\hline k. 240-243 & $\begin{array}{l}\text { m Krasnystaw [dot. wikariuszy i kaplicy św. Anny w kościele katedralnym w Kras- } \\
\text { nymstawie] }\end{array}$ \\
\hline k. $240-241 \mathrm{v}$ & dok. 1682 [dot. uposażenia kolegium wikariuszy w Krasnymstawie] \\
\hline k. $242-243$ & $\begin{array}{l}\text { Kumów, } 5 \times 1663 \\
\text { Tomasz Leżeński, biskup chełmski, eryguje beneficjum kapelana św. Anny w koś- } \\
\text { ciele katedralnym w Krasnymstawie i potwierdza w transumpcie dokument fun- } \\
\text { dacyjny Mikołaja Świrskiego, Krasnystaw, } 30 \text { I } 1649 \text { [zob. k. 163-165] }\end{array}$ \\
\hline k. 244-245v & m Gorzków \\
\hline k. $245 v-247 v$ & Lopie \\
\hline k. 246v-247 & $\begin{array}{l}\text { Kumów, } 25 \text { II } 1643 \\
\text { Biskup chełmski Paweł Piasecki, wobec zaginięcia pierwotnej, odnawia erekcję } \\
\text { parafii w Łopienniku }\end{array}$ \\
\hline k. $247 \mathrm{v}-249$ & Surhów \\
\hline k. 249-251 & Bończa \\
\hline k. 251-255 & m Wojsławice \\
\hline k. $251-253 \mathrm{v}$ & $\begin{array}{l}\text { Kumów, } 17 \text { VIII } 1595 \\
\text { Biskup chełmski eryguje (powtórna erekcja) parafię w Wojsławicach na podsta- } \\
\text { wie fundacji Mikołaja Czyżowskiego, chorążego ziemi chełmskiej, dziedzica } \\
\text { Wojsławic (Wojsławice, } 13 \text { sierpnia } 1595 \text { roku) [oblata w aktach ziemskich gra- } \\
\text { bowieckich, } 30 \times 1595 \text { ] }\end{array}$ \\
\hline k. 255-257 & Siennica Różana \\
\hline k. 257-264 & m Uchanie \\
\hline k. $260-260 v$ & $\begin{array}{l}\text { [b.m.r.] } \\
\text { Mikołaj Daniłowicz, podskarbi koronny z małżonką Heleną ze Służewa Uchańską } \\
\text { uposażają beneficjum altarzysty przy kościele parafialnym w Uchaniach przezna- } \\
\text { czając na ten cel } 100 \text { złotych rocznie oraz prezentują na to beneficjum Marcina } \\
\text { Muszeńskiego [Muszenius] [pol.] }\end{array}$ \\
\hline k. $260 v-263 v$ & dok. 1667 [dot. wsi Wolica] \\
\hline k. 264-269v & m Świerże [prawa i przywileje] \\
\hline k. $264-267$ & $\begin{array}{l}\text { Chełm, } 29 \text { VII } 1624 \\
\text { Maciej Łubieński biskup chełmski zawiera umowę z Hieronimem Jełowickim, } \\
\text { dziedzicem w Świerżach, która odnawia uposażanie parafii w Świerżach [pol.] }\end{array}$ \\
\hline
\end{tabular}




\begin{tabular}{|c|c|}
\hline k. $267-269 v$ & dok. 1691 [dot. uposażenia parafii Świerże] \\
\hline k. 272-279v & Siennica [prawa i przywileje] \\
\hline k. $272-273 v$ & $\begin{array}{l}\text { Siennica, } 26 \text { VI } 1468 \\
\text { Mikołaj „de Wocischowice”, kasztelan zawichojski i dziedzic Siennicy uposaża } \\
\text { kościół parafialny w Siennicy [oblata w aktach grodzkich krasnostawskich } 22 \text { II } \\
1614 \text { i } 10 \text { III 1678] }\end{array}$ \\
\hline k. $273 \mathrm{v}-275$ & dok. 1647 [dot. uposażenia parafii Siennica] \\
\hline k. $275 \mathrm{v}-279 \mathrm{v}$ & dok. 1663 [testament Jana Blinowskiego] \\
\hline k. $280-312 v$ & m Gorzków [prawa i przywileje] \\
\hline k. $280-283$ & $\begin{array}{l}\text { Kumów, } 8 \text { VI } 1626 \\
\text { Biskup chełmski Maciej Łubieński potwierdza odnowienie fundacji kościoła pa- } \\
\text { rafialnego w Gorzkowie dokonane w Krasnymstawie, 26 I 1623, przez Stanisława } \\
\text { Gorzkowskiego, dziedzica Gorzkowa, Czystej Dębiny, Olchowca i Wielkiegopola } \\
\text { [oblata tej fundacji w aktach grodzkich lubelskich, 10 VII 1624] }\end{array}$ \\
\hline k. $283-288$ & dok. 1626, 1643 [dot. uposażenia parafii Gorzków] \\
\hline k. $288 \mathrm{v}-289 \mathrm{v}$ & $\begin{array}{l}\text { Culhov [?], } 24 \text { VI } 1404 \\
\text { Biskup chełmski Stefan zezwala Mikołajowi Trąbie, dziedzicowi w Gorzkowie na } \\
\text { zamianę dziesięciny snopowej na pieniężną oraz przeznacza ją dla kościoła para- } \\
\text { fialnego w Gorzkowie [oblata, Zamość, } 10 \text { VIII 1640] }\end{array}$ \\
\hline k. $289 v-300$ & $\begin{array}{l}\text { Gorzków, } 20 \text { XI } 1453 \\
\text { Piotr, dziedzic w Gorzkowie wraz z żoną Elżbietą przekazują staw rybny na upo- } \\
\text { sażenie parafii w Gorzkowie [trans. Jana, biskupa chełmskiego, Krasnystaw, } 25 \\
\text { XI 1538] }\end{array}$ \\
\hline k. $300 v-303$ & $\begin{array}{l}\text { Gorzków, } 28 \times 1538 \\
\text { Jan Gorzkowski, dziekan chełmski i pleban w Gorzkowie zawiera ugodę z Krzysz- } \\
\text { tofem Gorzkowskim, notariuszem ziemi chełmskiej i Jakubem Gorzkowskim, } \\
\text { dziedzicami w Gorzkowie w sprawie uposażenia parafii [oblata w aktach ziem- } \\
\text { skich krasnostawskich, } 25 \text { XI 1538] }\end{array}$ \\
\hline k. $303-312 v$ & dok. 1643, 1644, 1669, 1689, 1699 [dot. uposażenia parafii w Gorzkowie] \\
\hline k. 316-321 & m Skierbieszów [prawa i przywileje parafii i prepozytury szpitalnej] \\
\hline k. $316-318 \mathrm{v}$ & [opis uposażenia parafii w Skierbieszowie] \\
\hline k. 319-321 & $\begin{array}{l}\text { Pawłów, } 18 \text { I } 1719 \\
\text { Biskup chełmski Krzysztof Szembek eryguje prepozyturę szpitalną w Skierbie- } \\
\text { szowie na podstawie dawniej zapisanych } 1500 \text { złotych oraz dodanych przez siebie } \\
500 \text { złotych (renta wykupna) }\end{array}$ \\
\hline k. 322-331v & Surhów [zawiera m.in. odpis wizytacji z 3 I 1672 oraz dekret reformacyjny] \\
\hline k. $325-325 \mathrm{v}$ & $\begin{array}{l}\text { b.m., } 23 \text { V } 1675 \\
\text { Biskup Stanisław Dąmbski potwierdza umowę między Stanisławem Mirz i Zu- } \\
\text { zanną z Kochanowskich Brzezickimi, dziedzicami wsi Surhów i Jakubem Szeliń- } \\
\text { skim, plebanem surhowskim zawartą } 5 \text { II } 1675 \mathrm{w} \text { sprawie doposażenia parafii } \\
\text { Surhów [faktyczna erekcja parafii, oblata w aktach grodzkich krasnostawskich, } \\
9 \text { I 1676, częściowo pol.] }\end{array}$ \\
\hline k. $326-331$ & dok. 1673, 1676, 1688, 1690, 1703, 1705 [dot. uposażenia parafii Surhów] \\
\hline k. 332-437v & m Zamość \\
\hline
\end{tabular}




\begin{tabular}{|c|c|}
\hline k. $332-335 v$ & $\begin{array}{l}\text { Kokenhausen, } 23 \text { IX } 1601 \\
\text { Król Zygmunt III Waza potwierdza erekcję kolegiaty w Zamościu, dokonaną } \\
\text { przez Stanisława Gomolińskiego, biskupa chełmskiego w Zamościu dn. } 5 \text { lipca } \\
1600 \text { r., na postawie fundacji Jana Zamoyskiego, kanclerza wielkiego koronnego, } \\
\text { dokonanej także } 5 \text { lipca } 1600 \text { r. [oblata w aktach Trybunału Koronnego w Lubli- } \\
\text { nie, } 4 \text { XI 1644, wyd. J.A. Wadowski, Wiadomości o profesorach Akademii Zamoj- } \\
\text { skiej, Warszawa 1899-1900, s. 82-86, na podstawie oblaty z } 3 \text { XI 1644] }\end{array}$ \\
\hline k. $335 v-339 v$ & $\begin{array}{l}\text { Zamość, } 5 \text { VII } 1600 \\
\text { Biskup Stanisław Gomoliński potwierdza fundację Akademii Zamojskiej dokona- } \\
\text { ną tego samego dnia przez Jana Zamoyskiego, kanclerza wielkiego koronnego } \\
\text { [wyd. J.A. Wadowski, } d z \text {. cyt., s. 76-81] }\end{array}$ \\
\hline k. $342-358$ & Iura capellam sancti Nicolai concernentia \\
\hline k. $342-345$ & $\begin{array}{l}\text { Zamość, } 31 \times 1649 \\
\text { Jan Skwarski, dziekan chełmski przekazuje sumę } 12 \text { tys. złotych na uposażenie } \\
\text { prepozyta oraz czterech mansjonarzy przy kaplicy św. Mikołaja, powiększając } \\
\text { tym samym dawną fundację dokonaną przez Mikołaja Kiślickiego, dziekana } \\
\text { chełmskiego i Macieja Leśniewskiego, kasztelana bełskiego, która wystarczała na } \\
\text { utrzymanie jedynie dwóch mansjonarzy [oblata w konsystorzu krasnostawskim, } \\
29 \text { XI 1649] }\end{array}$ \\
\hline k. $345-358$ & $\begin{array}{l}\text { dok. } 1621,1647 \text { [pol.], } 1648 \text { [pol.] 1649, } 1650 \text { [dok. dotyczące uposażenia kapli- } \\
\text { cy św. Mikołaja] }\end{array}$ \\
\hline k. 358 & Capella Mariae Magdalenae \\
\hline k. $358-360 v$ & $\begin{array}{l}\text { Capella sanctorum Andreae et Mathiae Apostolorum nunc dicta Sanctissimi Trin- } \\
\text { itatis }\end{array}$ \\
\hline k. $359-360 v$ & $\begin{array}{l}\text { Zamość, } 16 \text { VII } 1647 \\
\text { Jerzy Szornel, egzekutor testamentu Marka Nietyzy, zapisuje - zgodnie z jego } \\
\text { wolą - sumę } 3000 \text { złotych na uposażenie duchownego oraz utrzymanie kaplicy św. } \\
\text { Andrzeja i Macieja Apostołów, z czego } 2700 \text { złotych jako rentę wykupną, zaś } 300 \\
\text { złotych jako jednorazowy zapis na wyposażenie kaplicy [trans. pełnomocników } \\
\text { biskupa chełmskiego, Zamość, } 20 \text { VII 1649, pol.] }\end{array}$ \\
\hline k. $360 \mathrm{v}-361$ & Capella Sanctae Crucis \\
\hline k. $361-363$ & Capella sancti Casimiri alias Annunciatae \\
\hline k. $361-363$ & $\begin{array}{l}\text { Grabowiec, } 29 \times 1667 \\
\text { Andrzej Mateusz Chojnacki zapisuje w aktach grodzkich grabowieckich sumę } \\
2000 \text { złotych, z rocznym czynszem } 160 \text { złotych, dla duchownego przy kaplicy św. } \\
\text { Kazimierza i wyznacza dziekana kolegiackiego na opiekuna fundacji }\end{array}$ \\
\hline k. 363 & regest dok. 1685 [dotyczy zapisu mszalnego przy kaplicy św. Mikołaja] \\
\hline k. $363-363 v$ & $\begin{array}{l}\text { Obligationes vicariorum [wykaz obowiązków wynikających z zapisów pienięż- } \\
\text { nych na rzecz kolegium wikariuszy] }\end{array}$ \\
\hline k. $363 v-364$ & $\begin{array}{l}\text { Fundationes vicariorum [wykaz zapisów pieniężnych na rzecz kolegium wikariu- } \\
\text { szy] }\end{array}$ \\
\hline k. $364-365 v$ & $\begin{array}{l}\text { regesty dok. } 1690 \text { [dot. zapisu dla organisty], } 1658 \text { [dot. spalenia dokumentów } \\
\text { kolegiackich], } 1680 \text { [dot. zapisu dla kaplicy Marii Magdaleny], } 1662 \text { [dot. testa- } \\
\text { mentu Andrzeja Rzeszotarskiego], } 1708 \text { [dot. kaplicy różańcowej], } 1708 \text { [dot. ka- } \\
\text { nonii Wosińskiego] } 1715 \text { [dot. testamentu Sebastiana Leszczyńskiego, scholasty- } \\
\text { ka kolegiackiego], } 1715 \text { [dot. testamentu Wawrzyńca Sikorskiego, dziekana kole- } \\
\text { giackiego] }\end{array}$ \\
\hline
\end{tabular}




\begin{tabular}{|c|c|}
\hline k. $366-367$ & $\begin{array}{l}\text { Rzym, } 5 \text { XII } 1594 \\
\text { Papież Klemens VIII na prośbę Jana Zamoyskiego, kanclerza wielkiego koronne- } \\
\text { go i fundatora kapituły, zwalania jej członków z obowiązku ciągłej rezydencji } \\
\text { przy katedrze z powodu obowiązków akademickich, przy jednoczesnym zacho- } \\
\text { waniu uposażeń prałackich i kanonickich [trans. Jana Wioteski, notariusza apo- } \\
\text { stolskiego, Zamość, 1621] }\end{array}$ \\
\hline k. $368-372$ & $\begin{array}{l}\text { dok. } 1663 \text { [dot. obowiązków oraz uposażenia prałatów i kanoników zamojskich } \\
\text { oraz dziejów parafii w Szczebrzeszynie] }\end{array}$ \\
\hline k. $372-373$ & dok. 1658 [dot. spalenia dokumentów kolegiackich w czasie pożaru Zamościa] \\
\hline k. $373 v-378$ & $\begin{array}{l}\text { Zamość, } 20 \text { III } 1640 \\
\text { Katarzyna Zamoyska, zgodnie z wolą testamentową swojego męża Tomasza, kan- } \\
\text { clerza wielkiego koronnego, zapisuje wieś Pniówek i sołectwo Kawęczyn na upo- } \\
\text { sażenie seminarium duchownego dla } 12 \text { kleryków w Zamościu }\end{array}$ \\
\hline k. $378 v-380 v$ & $\begin{array}{l}\text { Zamość, } \times 1663 \\
\text { Stefan Zamoyski z żoną Dorotą z Laszczkowa zapisują sumę } 10 \text { tys. złotych loko- } \\
\text { wane na Orłowie, Wólce Orłowskiej i Kryniczkach na uposażenie seminarium dla } \\
5 \text { kleryków w Zamościu [pol.] }\end{array}$ \\
\hline k. $380 v-382$ & $\begin{array}{l}\text { Zamki nad rz. Gaują [In castris ultra Goviam], } 16 \times 1601 \\
\text { Jan Zamoyski, kanclerz wielki koronny, zapisuje } 10 \text { tys. na założenie banku po- } \\
\text { bożnego w Zamościu, opiekę nad którym mają sprawować dziekan i scholastyk } \\
\text { kolegiaty zamojskiej }\end{array}$ \\
\hline k. $382 v-388 v$ & $\begin{array}{l}\text { Decreta reformationis pro ecclesia collegiata et capitulo Zamoscensis, pro univer- } \\
\text { sitate inibidem vicariis, mansionariis, altaristis, confraternitatibus, capellis, hospi- } \\
\text { talibus, caeterisque locis piis sub tempus visitationis per ipsummet illustrissimum } \\
\text { excellentissimum ac reverendissimum dominum dominum Christophorum in } \\
\text { Stupow Szembek episcopum Chełmensem praepositum generalem Miechovien- } \\
\text { sem die } 29 \text { mensis aprilis anno currenti inhoatae et tandem die } 17 \text { maii eodem } \\
\text { terminatae, lata et publicata }\end{array}$ \\
\hline k. $389-397 \mathrm{v}$ & $\begin{array}{l}\text { Anno Domini 1714. Inventarium rerum mobilium et suppellectilis ecclesiae col- } \\
\text { legiatae Zamoscensis sabbato post festum sancti Bartholomaei Apostoli conscrip- } \\
\text { tum [pol.] }\end{array}$ \\
\hline k. 398-399 & $\begin{array}{l}\text { Legata pobożne do kaplice różańcowey w kościele farnym kollegiackim zamoy- } \\
\text { skim konnotowane od których prowizye dochodzą [z lat 1661-1713, pol.] }\end{array}$ \\
\hline k. $400-401$ & $\begin{array}{l}\text { Regestr legacyi pobożnych, które poupadały i od których prowizya nie dochodzi } \\
\text { do kaplice różańcowey w kościele farnym kollegiackim zamoyskim [z lat 1663- } \\
\text { 1674, pol.] }\end{array}$ \\
\hline k. $403-407 \mathrm{v}$ & $\begin{array}{l}\text { Inwentarz rzeczy do kaplice różańcowey należących kościoła kollegiaty zamoy- } \\
\text { skiey konnotowany in anno } 1715 \text { [pol.] }\end{array}$ \\
\hline k. $408-408 v$ & $\begin{array}{l}\text { Inwentarz papierów kaplicy literackiey w kościele farnym kollegiaty zamoyskiey } \\
\text { die } 21 \text { augusti anno Domini } 1714 \text { wypisany [z lat 1603-1694, pol.] }\end{array}$ \\
\hline k. $409-409 \mathrm{v}$ & Regestr summ legowanych do kaplice literackiey collegiaty zamoyskiey [pol.] \\
\hline k. $410-411 \mathrm{v}$ & $\begin{array}{l}\text { Inwentarz srebra, aparatów y innych rzeczy kaplicy bractwa literatorum Annun- } \\
\text { tiationis Beatae Virginis Mariae die } 29 \text { mai anno Domini } 1714 \text { spisany [pol.] }\end{array}$ \\
\hline k. $412-414 \mathrm{v}$ & $\begin{array}{l}\text { Connotatio summarum tam xenodochiorum quam praepositi noviter fundati a pe- } \\
\text { rillustri reverendissimo domino Laurentio Sikorski decano infulato Zamoscensi, } \\
\text { Szczebrzesensi Tarnogrodiensi praeposito [z lat 1591-1715] }\end{array}$ \\
\hline
\end{tabular}




\begin{tabular}{|c|c|}
\hline k. 418-419 & $\begin{array}{l}\text { dok. } 1669 \text { [potwierdzenie praw i przywilejów Akademii Zamojskiej przez króla } \\
\text { Michała Korybuta Wiśniowieckiego, trans. Jana III Sobieskiego z 1676, druk. Za- } \\
\text { mość 1688] }\end{array}$ \\
\hline k. $420-422 v$ & $\begin{array}{l}\text { dok. } 1682 \text { [tzw. ugoda jaworowska, dot. prawa patronatu ordynatów oraz jurys- } \\
\text { dykcji biskupa chełmskiego nad Akademią Zamojską] }\end{array}$ \\
\hline k. $423-425 v$ & $\begin{array}{l}\text { Kokenhausen, } 23 \text { IX } 1601 \\
\text { Król Zygmunt III Waza potwierdza erekcję kolegiaty w Zamościu, dokonaną } \\
\text { przez Stanisława Gomolińskiego, biskupa chełmskiego w Zamościu dn. } 5 \text { VII } \\
1600 \text {, na postawie fundacji Jana Zamoyskiego, kanclerza wielkiego koronnego, } \\
\text { dokonanej także } 5 \text { VII } 1600 \text { [oblata w aktach Trybunału Koronnego w Lublinie, } \\
4 \text { XI 1644, wyd. J.A. Wadowski, } d z \text {. cyt., s. 82-86, na podstawie oblaty z } 3 \text { XI } \\
\text { 1644, zob. k. 332-335v] }\end{array}$ \\
\hline k. $427-427^{\mathrm{a}} \mathrm{v}$ & $\begin{array}{l}\text { Zamość, } 5 \text { VII } 1600 \\
\text { Biskup Stanisław Gomoliński potwierdza fundację Akademii Zamojskiej dokona- } \\
\text { ną tego samego dnia przez Jana Zamoyskiego, kanclerza wielkiego koronnego } \\
\text { [wyd. J.A. Wadowski, dz. cyt., s. } 76-81 \text {; zob. k. 335v-339v] }\end{array}$ \\
\hline k. $428^{\mathrm{a}-428^{\mathrm{c}}}$ & dok. 1715 [dot. noszenia mantoletów przez członków kapituły] \\
\hline k. 429-431 & $\begin{array}{l}\text { Rzym, } 5 \text { VI } 1617 \\
\text { Papież Paweł V wydaje breve potwierdzające fundację Akademii Zamojskiej, } \\
\text { ograniczając jednocześnie prawa biskupa chełmskiej względem niej na korzyść } \\
\text { ordynatów zamojskich [trans. Jana Andrzeja Próchnickiego, arcybiskupa lwow- } \\
\text { skiego, Lwów, } 17 \text { V 1619] }\end{array}$ \\
\hline k. $435-437 v$ & $\begin{array}{l}\text { Puncta reformationis ecclesiae collegiatae Zamoscensis venerabili capitulo, Aca- } \\
\text { demiae, seminario, hospitali et aliis piis locis in eodem civitate existentibus re- } \\
\text { licta a perillustribus et admodum reverendis dominis Iacobo a Rostkow Rost- } \\
\text { kowski canonico Chełmensi Dubensi Grabovecensi praeposito et Francisco Ma- } \\
\text { linowski I.U.D. canonico Chełmensi Skierbieszoviensi praeposito ex commissio- } \\
\text { ne plenaria illustrissimi et reverendissimi domini domini Stanislai a Buzenin } \\
\text { Pstrokoński Dei et Apostolicae Sedis gratia episcopi Chełmensis, abbatiae Tine- } \\
\text { censis administratoris perpetui anno Domini } 1647 \text { die } 21 \text { mensis novembris }\end{array}$ \\
\hline k. 439-462 & Sitaniec \\
\hline k. $439-440$ & $\begin{array}{l}\text { Sitaniec, } 20 \text { VIII } 1585 \text { [pomyłka w datacji, powinno być 1485] } \\
\text { Jan Sitański, dziedzic Sitańca, uposaża kościół parafialny w tej miejscowości [ob- } \\
\text { lata w Krasnymstawie, 1644] }\end{array}$ \\
\hline k. $440 v-443$ & $\begin{array}{l}\text { Sitaniec, } 7 \text { VIII } 1647 \\
\text { Mikołaj Oborski, kanonik krakowski, Andrzej Świnarski, kanonik poznański i Ja- } \\
\text { kub Rostkowski, kanonik chełmski deputowani Trybunału Koronnego, wyzna- } \\
\text { czają uposażenie parafii w Sitańcu [pol.] }\end{array}$ \\
\hline k. $443-444$ & dok. 1647 [dot. wprowadzenia w posiadanie majątku parafii Sitaniec] \\
\hline k. $444 \mathrm{v}-445$ & dok. 1660 [dot. uposażenia parafii Sitaniec, pol.] \\
\hline k. $445 \mathrm{v}$ & dok. 1699 [dot. poświęcenia kościoła parafialnego w Sitańcu] \\
\hline k. $454 \mathrm{v}-457$ & dok. 1690 [dot. uposażenia parafii Sitaniec] \\
\hline k. $457 \mathrm{v}-459 \mathrm{v}$ & dok. 1707 [dot. święceń i prowizji wikariusza w parafii Sitaniec] \\
\hline k. 463-492 & Wielącza \\
\hline
\end{tabular}




\begin{tabular}{|c|c|}
\hline k. $467 \mathrm{v}-468$ & $\begin{array}{l}\text { Wielącza, } 13 \text { XII } 1552 \\
\text { Andrzej Górka, kasztelan międzyrzecki, dziedzic Szczebrzeszyna zapisuje parafii } \\
\text { w Wielączy dziesięcinę z folwarków Złojec, Niedzieliska, Płoskie i Wieprzec oraz } \\
\text { starostw Wielącza i Bortatycze [pol.] }\end{array}$ \\
\hline k. 468-469 & $\begin{array}{l}\text { Poznań, } 16 \text { VII } 1591 \\
\text { Stanisław Górka, wojewoda poznański, dziedzic powiatu szczebrzeskiego naka- } \\
\text { zuje ludności poddanej folwarków Bortatycze, Wieprzec, Złojec, Niedzieliska } \\
\text { i Wielącza wypłacać dziesięciny plebanowi w Wielączy [pol.] }\end{array}$ \\
\hline k. $469-470 \mathrm{v}$ & dok. 1636, 1641, 1642 [dot. dziesięcin dla parafii w Wielączy, pol.] \\
\hline k. 471 & $\begin{array}{l}\text { Szczebrzeszyn, } 5 \text { VI } 1589 \\
\text { Belina z Niedzielisk i Stanisław Stan z Wielączy oświadczają przed aktami wój- } \\
\text { towskimi, że dziesięciny z folwarków Wielącza, Niedzieliska, Płoskie, Bortaty- } \\
\text { cze, Złojec, Wieprzec i Nielisz od dawna są oddawane parafii w Wielączy [pol.] }\end{array}$ \\
\hline k. $471-488 v$ & $\begin{array}{l}\text { dok. } 1653,1659,1659,1680,1699,1681,1686,1701,1701,1699 \text { [dot. uposaże- } \\
\text { nia parafii Wielącza, pol. z wyjątkiem dok. } 1680 \text { i 1701] }\end{array}$ \\
\hline k. $489 \mathrm{v}-491$ & dok. 1641 [dot. odprawiania mszy w kaplicy w Nieliszu, pol.] \\
\hline k. 491-492 & $\begin{array}{l}\text { Zamość, } 14 \text { VI } 1709 \\
\text { Tomasz Józef Zamoyski zapisuje pół łanu gruntu, łąkę oraz sumę } 1 \text { tys. złotych na } \\
\text { uposażenie bractwa różańcowego oraz promotora przy kościele parafialnym } \\
\text { w Wielączy [pol.] }\end{array}$ \\
\hline k. $499-505 v$ & m Szczebrzeszyn \\
\hline k. $502-503 \mathrm{v}$ & $\begin{array}{l}\text { Szczebrzeszyn, } 16 \text { I } 1398 \\
\text { Jakub, arcybiskup lwowski, na prośbę Dymitra z Goraja poddaje cały powiat } \\
\text { szczebrzeski władzy duchownej arcybiskupów lwowskich oraz reguluje stosunki } \\
\text { dziesięcinne [trans. Zygmunta III, Warszawa, 22 VII 1593] }\end{array}$ \\
\hline k. $503 \mathrm{v}-504$ & dok. 1649 [dot. uposażenia parafii w Szczebrzeszynie, pol.] \\
\hline k. 506-514 & Stary Zamość \\
\hline k. 507-509 & $\begin{array}{l}\text { Stary Zamość, } 14 \text { VIII } 1593 \\
\text { Stanisław Gomoliński, biskup chełmski na prośbę Stanisława Wojciecha ze Skier- } \\
\text { niewic, plebana oraz kanclerza Jana Zamoyskiego, dziedzica w Starym Zamościu } \\
\text { odnawia erekcję kościoła parafialnego w tej wsi }\end{array}$ \\
\hline k. $510-514$ & $\begin{array}{l}\text { Stary Zamość, } 15 \text { III } 1644 \\
\text { Paweł Piasecki, biskup chełmski, eryguje beneficjum prepozyta szpitalnego przy } \\
\text { kościele parafialnym w Starym Zamościu na podstawie fundacji ordynata Wacła- } \\
\text { wa Zamoyskiego, kasztelana lwowskiego wydanej w Lublinie } 2 \text { V } 1642 \text { [pol.] } \\
\text { i oblatowanej w Trybunale Koronnym } 28 \text { VI } 1642\end{array}$ \\
\hline k. 517-520v & m Świerże \\
\hline k. $520 v-529 v$ & Uhrusk \\
\hline k. $520 v-527$ & $\begin{array}{l}\text { dok. } 1638,1639,1656 \text { [pol.], } 1654 \text { [pol.], } 1668 \text { [pol.], } 1707 \text { [dot. uposażenia pa- } \\
\text { rafii Uhrusk] }\end{array}$ \\
\hline k. 529v-533 & m Sawin \\
\hline k. $529 \mathrm{v}-535$ & dok. 1631, 1645 [dot. uposażenia parafii Sawin] \\
\hline k. $532-533$ & $\begin{array}{l}\text { Chylin, } 12 \text { VI } 1611 \\
\text { Paweł Chyliński zapisuje w testamencie, ze swoich dóbr dziedzicznych Chylina } \\
\text { i Busówna, sumę } 100 \text { zł rocznie na uposażenie beneficjum altarzysty w kościele } \\
\text { parafialnym w Sawinie [oblata w aktach grodzkich chełmskich, } 14 \text { VI 1611, pol.] }\end{array}$ \\
\hline k. 535-537v & Czułczyce \\
\hline
\end{tabular}




\begin{tabular}{|c|c|}
\hline k. $537 v-553$ & $\begin{array}{l}\text { Kumów [m.in. odpis dekretu reformacyjnego z } 19 \text { XII } 1637 \text { i opis uposażenia } \\
\text { parafii z wizytacji biskupa Żegockiego z } 12 \text { I 1672] }\end{array}$ \\
\hline k. $538 v-540$ & $\begin{array}{l}\text { Kumów, } 29 \text { VI } 1434 \text { - Jana zw. Biskupcem, biskup chełmski uposaża i eryguje } \\
\text { parafię w Kumowie [oblata w aktach grodzkich krasnostawskich, } 4 \text { I } 1610 \text { i w ak- } \\
\text { tach grodzkich chełmskich, } 25 \text { IV 1653] }\end{array}$ \\
\hline k. $540-548$ & $\begin{array}{l}\text { dok. } 1655 \text { [pol.], 1670, 1676, 1675, 1694, 1699, } 1692 \text { [dot. uposażenia parafii } \\
\text { Kumów] }\end{array}$ \\
\hline k. $551-553$ & dok. 1645, 1703, 1712 [dot. uposażenia parafii Kumów] \\
\hline k. 553-557 & m Chelm \\
\hline k. $557-563 \mathrm{v}$ & m Pawłów \\
\hline k. $561 v-563$ & $\begin{array}{l}\text { Kumów, } 24 \text { VII } 1624 \\
\text { Maciej Łubieński, biskup chełmski zatwierdza fundację szpitala w Pawłowie, do- } \\
\text { konaną przez Macieja Mogilnickiego, dziedzica w Mogilnicy i Hańsku, dokonaną } \\
\text { w Mogilnicy } 18 \text { VII } 1624 \text { [pol.] }\end{array}$ \\
\hline k. $563 v-566 v$ & Olchowiec \\
\hline k. $566 v-603$ & Wereszczyn [przywileje spisa \\
\hline k. $574-576 v$ & $\begin{array}{l}\text { Podhajce, } 13 \text { IV } 1634 \\
\text { Zofia Tyszkiewiczowa, wojewodzina trocka uposaża kościół parafialny w Weresz- } \\
\text { czynie [oblata w konsystorzu krasnostawskim, } 7 \text { VI 1634, pol.] }\end{array}$ \\
\hline k. $576 \mathrm{v}-584$ & $\begin{array}{l}\text { dok. } 1658 \text { [pol.], } 1666 \text { [pol.], 1662, } 1670 \text { [pol.], 1670, } 1670 \text { [dot. uposażenia pa- } \\
\text { rafii w Wereszczynie] }\end{array}$ \\
\hline k. $584-587 \mathrm{v}$ & dok. 1650, 1693 [dotyczy uposażenia kapelanii św. Anny w Wereszczynie] \\
\hline k. $587 \mathrm{v}-588 \mathrm{v}$ & $\begin{array}{l}\text { Wereszczyn, } 15 \text { VIII } 1669 \\
\text { Kazimierz Noczkowski, pleban w Wereszczynie i Szymon Aleksander Mogilni- } \\
\text { cki, podstarości grodzki horodelski uposażają szpital przy parafii w Wereszczy- } \\
\text { nie }\end{array}$ \\
\hline k. $588 \mathrm{v}-590 \mathrm{v}$ & dok. 1669 [dot. uposażenia bractwa różańcowego w Wereszczynie] \\
\hline k. $590 v-599 \mathrm{v}$ & $\begin{array}{l}\text { dok. } 1671 \text { [pol.], 1687, 1692, 1669, } 1683 \text { [pol.], 1643, } 1647 \text { [pol.], } 1653 \text { [dot. } \\
\text { uposażenia parafii i szpitala w Wereszczynie] }\end{array}$ \\
\hline k. $599 \mathrm{v}-600 \mathrm{v}$ & [odpis dekretu reformacyjnego wizytacji parafii w Wereszczynie z $2 \times 1660$ ] \\
\hline k. $600 \mathrm{v}-603$ & dok. 1674, 1685, 1685, 1693 [dot. uposażenia parafii w Wereszczynie] \\
\hline k. 604-607v & m Pawłów [zob. k. 557-563v] \\
\hline k. 608-609 & Uhrusk [opis wyposażenia ruchomego, pol.] \\
\hline k. 616-620v & Chelm [dokumenty dotyczące kolegium pijarów] \\
\hline k. $616-618 v$ & $\begin{array}{l}\text { Krasnystaw, } 17 \text { VII } 1671 \text { [błędnie, powinno być: 1672] } \\
\text { Krzysztof Żegocki, biskup chełmski, eryguje kolegium pijarów w Chełmie i in- } \\
\text { korporuje doń tamtejszą parafię, związaną z nią prebendę NMP oraz prepozyturę } \\
\text { szpitalną w Chełmie }\end{array}$ \\
\hline k. $619-620 \mathrm{v}$ & dok. 1667, 1673 [dot. uposażenia i erekcji kolegium pijarów w Chełmie] \\
\hline k. $621^{\mathrm{a}}-621^{\mathrm{b}}$ & m Zamość [fragment dekretu reformacyjnego, 1715; zob. k. 382v-388v] \\
\hline k. 622-626v & $\begin{array}{l}\text { m Chelm [opis kościoła parafialnego, szpitalnego i kolegium pijarów, } 13 \text { VI } \\
\text { 1687] }\end{array}$ \\
\hline k. 628-648v & Olchowiec \\
\hline
\end{tabular}




\begin{tabular}{|c|c|}
\hline k. $630 \mathrm{v}-633 \mathrm{v}$ & $\begin{array}{l}\text { Krasnystaw, } 11 \text { VI } 1457 \\
\text { Jan Kraska, biskup chełmski, oddziela kościół w Olchowcu od parafii w Łyszczu } \\
\text { i eryguje jako samodzielną parafię [trans. Jakuba Buczackiego, biskupa chełm- } \\
\text { skiego, Sawin, } 20 \text { VI 1534; oblata w aktach grodzkich chełmskich, } 17 \text { VI 1625] }\end{array}$ \\
\hline k. $634-648$ & $\begin{array}{l}\text { dok. } 1603,1483,1664 \text { [pol.], 1665, 1648, } 1695 \text { [pol.], } 1696 \text { [pol.] [dot. uposaże- } \\
\text { nia i wyposażenia parafii Olchowiec] }\end{array}$ \\
\hline k. 650-658v & m Maciejów [wzmiankowany też kościół szpitalny] \\
\hline k. $658 v-665 v$ & m Ratno \\
\hline k. $662-665 \mathrm{v}$ & dok. 1714 [pol.], 1714 [pol.] [dot. uposażenia parafii w Ratnie] \\
\hline k. 668-680 & m Maciejów \\
\hline k. $669-678 \mathrm{v}$ & $\begin{array}{l}\text { dok. } 1636 \text { [pol.], } 1617 \text { [pol.], } 1668 \text { [pol.], } 1668 \text { [pol.], } 1667 \text { [pol.], } 1650 \text { [pol.], } \\
1654 \text { [pol.] [dot. uposażenia parafii w Maciejowie] }\end{array}$ \\
\hline k. $678 \mathrm{v}-680$ & $\begin{array}{l}\text { Maciejów, } 8 \text { III } 1596 \\
\text { Anna z Wiśniowa Sapieżyna, wojewodzina witebską, starościna wielicka i sura- } \\
\text { cka odnawia uposażenie parafii w Maciejowie [pol.] [trans. Macieja Łubieńskie- } \\
\text { go, biskupa chełmskiego, Kumów, } 19 \text { V 1627; oblata w aktach biskupa chełm- } \\
\text { skiego, } 19 \text { V 1627] }\end{array}$ \\
\hline k. 680-693 & m Przewaly \\
\hline k. $680-681$ & $\begin{array}{l}\text { Przewały, } 26 \text { XI } 1464 \\
\text { Hurko, stolnik chełmski i dziedzic Przewał uposaża kościół parafialny w Przewa- } \\
\text { łach }\end{array}$ \\
\hline k. $681-685$ & dok. 1694 [pol.], 1679 [pol.], 1687 [pol.] [dot. uposażenia parafii w Przewałach] \\
\hline k. $688-689$ & $\begin{array}{l}\text { Przewały, } 26 \text { XI } 1464 \\
\text { Hurko, stolnik chełmski i dziedzic Przewał uposaża kościół parafialny w Przewa- } \\
\text { łach [zob. k. 680-681] }\end{array}$ \\
\hline k. $693 \mathrm{v}-695$ & m Korytnica \\
\hline k. 695-700 & m Dubienka \\
\hline k. 712-713v & m Opalin \\
\hline k. 714-715 & Radziechów, augustianie eremici \\
\hline k. $716-756 \mathrm{v}$ & m Hrubieszów \\
\hline k. $717 \mathrm{v}-719$ & $\begin{array}{l}\text { Lwów, } 1 \times 1400 \\
\text { Król Władysław Jagiełło uposaża kościół parafialny w mieście Hrubieszowie } \\
\text { [wyd. ZDM VI, s. 176-178] }\end{array}$ \\
\hline k. $719 \mathrm{v}-721$ & $\begin{array}{l}\text { Troki, } 3 \text { IV } 1449 \\
\text { Król Kazimierz Jagiellończyk, na prośbę plebana Jakuba z Szamotuł, potwierdza } \\
\text { uposażenie kościoła parafialnego w Hrubieszowie }\end{array}$ \\
\hline k. $721-733 \mathrm{v}$ & $\begin{array}{l}\text { dok. 1643, } 1659 \text { [pol.], 1643, 1643, 1643, 1661, 1655, 1655, } 1671 \text { [pol.] [dot. } \\
\text { uposażenia parafii w Hrubieszowie] }\end{array}$ \\
\hline k. $733 v-734$ & $\begin{array}{l}\text { Kumów, } 29 \text { XI } 1629 \\
\text { Remigiusz Koniecpolski, biskup chełmski przyłącza parafię w Czerniczynie do } \\
\text { parafii w Hrubieszowie }\end{array}$ \\
\hline k. $734-740 \mathrm{v}$ & dok. $1603,1629,1625$, b.r. [dot. uposażenia parafii w Hrubieszowie] \\
\hline k. $740 \mathrm{v}-744$ & $\begin{array}{l}\text { Rzym, } 15 \text { I } 1710 \\
\text { Papież Klemens XI wyraża zgodę na inkorporację parafii w Hrubieszowie do ka- } \\
\text { pituły katedralnej w Krasnymstawie [zob. k. 55-58] }\end{array}$ \\
\hline
\end{tabular}




\begin{tabular}{|c|c|}
\hline k. 744-746 & $\begin{array}{l}\text { Krasnystaw, } 1 \text { I } 1712 \\
\text { Walenty Czulski, wikariusz in spiritualibus i oficjał generalny chełmski, z polece- } \\
\text { nia papieża Klemensa VII, powiększa uposażenie kapituły katedralnej w Kras- } \\
\text { nymstawie przez inkorporację parafii w Hrubieszowie oraz określa uposażenie } \\
\text { wikariusza wieczystego tej parafii [zob. k. 58-60v] }\end{array}$ \\
\hline k. $746-747 \mathrm{v}$ & dok. 1713,1713 [dot. obsady parafii w Hrubieszowie] \\
\hline k. $758-761 \mathrm{v}$ & Trzeszczany \\
\hline k. $759 \mathrm{v}-761$ & dok. 1637 [pol.] [dot. uposażenia parafii w Trzeszczanach] \\
\hline k. $761 \mathrm{v}-765 \mathrm{v}$ & Moniatycze \\
\hline k. $763 \mathrm{v}-765$ & dok. 1704, 1607 [dot. uposażenia parafii w Moniatyczach] \\
\hline k. $766-770 v$ & m Horodlo \\
\hline k. $768-769 \mathrm{v}$ & dok. 1671, 1704 [pol.] [dot. uposażenia parafii w Horodle] \\
\hline k. $770 \mathrm{v}-772$ & m Hrubieszów, kłs. \\
\hline k. $772-778$ & m Kryłów [m.in. prawa i przywileje] \\
\hline k. $772-773 v$ & $\begin{array}{l}\text { Kryłów, } 24 \times 1638 \\
\text { Mikołaj Ostroróg, podczaszy koronny, odnawia uposażenie parafii w Kryłowie } \\
\text { [pol.] }\end{array}$ \\
\hline k. $773 v-775 v$ & $\begin{array}{l}\text { dok. } 1686 \text { [pol.], } 1689 \text { [pol.], } 1690 \text { [pol.], 1691, } 1663 \text { [pol.] [dot. uposażenia para- } \\
\text { fii w Kryłowie] }\end{array}$ \\
\hline k. $778-783$ & T \\
\hline k. $780 \mathrm{v}-781 \mathrm{v}$ & $\begin{array}{l}\text { [b.m.r.] } \\
\text { Piotr Gołdacz, wojski buski i dziedzic Uhrynowa uposaża kościół parafialny w Uh- } \\
\text { rynowie [powtórna fundacja, oblata w aktach grodzkich bełskich, } 9 \times 1591 \text {; obla- } \\
\text { ta w aktach ziemskich bełskich, } 13 \text { I 1592][pol.] }\end{array}$ \\
\hline k. $783 \mathrm{v}-799 \mathrm{v}$ & m Augustów [inaczej Mosty Wielkie, prawa i przywileje] \\
\hline k. $783 \mathrm{v}-784 \mathrm{v}$ & $\begin{array}{l}\text { Kraków, } 23 \text { VII } 1549 \\
\text { Zygmunt August uposaża kościół parafialny w mieście Augustowie [oblata w ak- } \\
\text { tach grodzkich lwowskich, } 1 \text { IX 1694] }\end{array}$ \\
\hline k. $784 \mathrm{v}-793$ & $\begin{array}{l}\text { dok. } 1642,1645,1645,1662,1662,1662,1663 \text { [dot. uposażenia parafii w Augu- } \\
\text { stowie i prepozytury szpitalnej w Bełzie]] }\end{array}$ \\
\hline k. $793-793 v$ & dok. 1610 [dot. stosunków z Żydami w Augustowie] \\
\hline k. $793 \mathrm{v}-797 \mathrm{~V}$ & dok. 1677 [pol.], 1700 [dot. uposażenia parafii w Augustowie] \\
\hline k. $798-798 v$ & dok. 1714 [pol.] [dot. uposażenia parafii w Augustowie] \\
\hline k. $800-804 v$ & Oszczów [m.in. prawa i przywileje] \\
\hline k. $800-802$ & $\begin{array}{l}\text { Oszczów, } 5 \text { V } 1468 \\
\text { Krystyn z Oszczowa, sędzia ziemski bełski, Jan z Honiatynia, Mikołaj z Oskier- } \\
\text { czyc, Jan z Horoszczyc i Bielawa z Rulikowa uposażają kościół parafialny w Osz- } \\
\text { czowie [trans. Marka, kardynała i legata papieskiego, Kraków, } 9 \text { VII 1472] }\end{array}$ \\
\hline k. $802-803$ & $\begin{array}{l}\text { Bełz, } 27 \text { IV } 1537 \\
\text { Paweł i Katarzyna Przedborscy uposażają beneficjum altarzysty przy kościele pa- } \\
\text { rafialnym w Oszczowie }\end{array}$ \\
\hline k. $804 \mathrm{v}-807$ & Rzeplin \\
\hline k. $807 \mathrm{v}-819 \mathrm{v}$ & Żerniki [m.in. prawa i przywileje] \\
\hline
\end{tabular}




\begin{tabular}{|c|c|}
\hline k. $807 v-809 v$ & $\begin{array}{l}\text { Podhorce, } 24 \text { IX } 1472 \\
\text { Paweł, biskup chełmski eryguje kościół parafialny w Żernikach i potwierdza } \\
\text { w transumpcie dokument fundacyjny Mikołaja Zbrożek z Żernik, wojskiego beł- } \\
\text { skiego oraz Jakuba z Podlodowa, wojskiego horodelskiego, Podhorce, } 24 \text { VIII } \\
1472 \text { [oblata w aktach grodzkich bełskich, } 30 \text { IV 1636] }\end{array}$ \\
\hline k. $812-814$ & $\begin{array}{l}\text { Podhorce, } 24 \text { IX } 1472 \\
\text { Paweł, biskup chełmski eryguje kościół parafialny w Żernikach i potwierdza } \\
\text { w transumpcie dokument fundacyjny Mikołaja Zbrożek z Żernik, wojskiego beł- } \\
\text { skiego oraz Jakuba z Podlodowa, wojskiego horodelskiego, Podhorce, } 24 \text { VIII } \\
1472 \text { [oblata w aktach grodzkich bełskich, } 30 \text { IV 1636, zob. k. 807v-809] }\end{array}$ \\
\hline k. $816-819$ & $\begin{array}{l}\text { dok. } 1652 \text { [testament Krzysztofa Żulińskiego, pol.], 1645, 1622, 1704, } 1699 \text { [dot. } \\
\text { uposażenia parafii w Żernikach] }\end{array}$ \\
\hline k. $820-853$ & Ostrów \\
\hline k. $820-820 \mathrm{v}$ & $\begin{array}{l}\text { Ostrów, } 25 \text { VI } 1409 \\
\text { Grzegorz, biskup włodzimierski, eryguje kościół parafialny w Ostrowie ufundo- } \\
\text { wany przez Wiganda, chorążego płockiego, Mikołaja z Cebłowa i Jerzego z Sie- } \\
\text { bieczowa [oblata w aktach ziemskich bełskich, } 16 \times 1595 \text {; wyd. ZDM V, s. 216- } \\
218 \text { ] }\end{array}$ \\
\hline k. $822 \mathrm{v}-849 \mathrm{v}$ & $\begin{array}{l}\text { dok. } 1646 \text { [testament Remigiusza Kaznowskiego, pol.], dok. } 1714 \text { [pol.], } 1645 \\
\text { [fragm. pol.], 1662, 1666 [pol.], 1679, } 1710 \text { [pol.], } 1712 \text { [pol.], 1644, 1646, 1663, } \\
\text { 1675, 1681, } 1686 \text { [pol.], } 1686 \text { [pol.], 1612, 1644, } 1652 \text { [pol.] } 1644 \text { [dot. uposaże- } \\
\text { nia parafii w Ostrowie], b.r. [testament Jana Czajkowskiego, plebana w Ostrowie, } \\
\text { pol.], 1656, 1665, 1668, } 1646 \text { [fragm. pol.], 1646, 1637, b.r. [pol.], } 1675 \text { [dot. } \\
\text { uposażenia parafii w Ostrowie], 1624 [testament Konstancji Jezierskiej, pol.], } \\
1644 \text { [dot. uposażenia parafii w Ostrowie], } 1651 \text { [testament Melchiora Popław- } \\
\text { skiego, pol.], } 1661 \text { [pol.] [dot. uposażenia parafii w Ostrowie], } 1656 \text { [testament } \\
\text { Andrzeja Suchodolskiego, pol.], 1664, 1657, 1671 [dot. uposażenia parafii w Os- } \\
\text { trowie], } 1676 \text { [testament Stefana Stępkowskiego, pol.] } 1688 \text { [dot. uposażenia pa- } \\
\text { rafii w Ostrowie] }\end{array}$ \\
\hline k. $850-850 \mathrm{v}$ & $\begin{array}{l}\text { Ostrów, } 19 \text { IV } 1484 \\
\text { Marcin z Ostrowa, podkomorzy bełski, uposaża beneficjum altarzysty przy koś- } \\
\text { ciele parafialnym w Ostrowie [oblata w aktach ziemskich bełskich, 28 VI 1627] }\end{array}$ \\
\hline k. $851 \mathrm{v}-853$ & $\begin{array}{l}\text { dok. } 1663 \text { [tekst wizytacji kościoła w Ostrowie przeprowadzonej przez Walentego } \\
\text { Turobojskiego, archidiakona chełmskiego] }\end{array}$ \\
\hline k. $856-863$ & m Sokal \\
\hline k. $863-865 \mathrm{v}$ & m Sokal, brygidki \\
\hline k. $865 \mathrm{v}-874 \mathrm{v}$ & Tartaków \\
\hline k. $868 \mathrm{v}-872$ & $\begin{array}{l}\text { Kumów, } 20 \text { XII } 1606 \\
\text { Jerzy Zamoyski, biskup chełmski, odnawia erekcję parafii w Tartakowie i po- } \\
\text { twierdza w transumpcie dokument fundacyjny Katarzyny i Adama Trzcińskich, } \\
\text { Tartaków, } 22 \text { XI } 1605 \text { [oblata w aktach ziemskich bełskich, 12 I 1609] }\end{array}$ \\
\hline k. $872-873 v$ & $\begin{array}{l}\text { Krasnystaw, } 19 \text { V } 1668 \\
\text { Kazimierz Czermiński, dziedzic w Tartakowie uposaża altrzystę przy kościele pa- } \\
\text { rafialnym w Tartakowie }\end{array}$ \\
\hline k. $874 \mathrm{v}-878 \mathrm{v}$ & m Stojanów \\
\hline k. $878 \mathrm{v}-881 \mathrm{v}$ & Stanin \\
\hline k. $882-893$ & m Dobrotwór [m.in. prawa i przywileje] \\
\hline
\end{tabular}




\begin{tabular}{|c|c|}
\hline k. $882-891$ & $\begin{array}{l}\text { dok. } 1641 \text { [tzw. nowa fundacja], 1600, 1612, 1626, 1644, } 1645 \text { [dot. uposażenia } \\
\text { parafii w Dobrotworze] }\end{array}$ \\
\hline k. $893-899 v$ & Ostrów \\
\hline k. $899 v-932$ & m Waręż [m.in. prawa i przywileje] \\
\hline k. $899 \mathrm{v}-901$ & $\begin{array}{l}\text { [b.m.r.] } \\
\text { Jakub Buczacki, biskup chełmski eryguje [powtórna erekcja] kościół parafialny } \\
\text { w Warężu oraz potwierdza w transumpcie dokument fundacyjny Krystiana z Osz- } \\
\text { czowa wydany } 20 \text { IV } 1528\end{array}$ \\
\hline k. $901-901 \mathrm{v}$ & $\begin{array}{l}\text { Waręż, } 26 \text { IX } 1663 \\
\text { Tomasz Leżeński, biskup chełmski inkorporuje parafię w Chochłowie, upadłą w cza- } \\
\text { sie reformacji, do parafii w Warężu }\end{array}$ \\
\hline k. $901 \mathrm{v}-914 \mathrm{v}$ & $\begin{array}{l}\text { dok. } 1653,1671,1671,1672 \text { [pol.], } 1672 \text { [dot. uposażenia parafii w Warężu], } \\
1670 \text { [testament ks. Kazimierza Kożuchowskiego, pol.], 1666, 1694, } 1698 \text { [pol.], } \\
1698 \text { [dot. uposażenia parafii w Warężu], } 1704 \text { [dot. przeniesienia siedziby para- } \\
\text { fii] }\end{array}$ \\
\hline k. $915 \mathrm{v}-917$ & $\begin{array}{l}\text { Skierbieszów, } 9 \text { VI } 1704 \\
\text { Biskup Mikołaj Wyżycki eryguje beneficjum prepozyta szpitalnego z obowiązka- } \\
\text { mi promotora bractwa różańcowego przy parafii w Warężu na podstawie fundacji } \\
\text { Błażeja Pampeckiego miejscowego plebana }\end{array}$ \\
\hline k. $917-922$ & $\begin{array}{l}\text { dok. 1705, 1711, 1712, } 1713 \text { [pol.] [dot. bractwa różańcowego i uposażenia para- } \\
\text { fii Waręż] }\end{array}$ \\
\hline k. $922 v-924$ & $\begin{array}{l}\text { Waręż, } 6 \text { XI } 1714 \\
\text { Krzysztof Szembek, biskup chełmski eryguje beneficjum kaznodziei przy parafii } \\
\text { w Warężu na podstawie fundacji Dominika Pampeckiego z } 1711 \text { roku }\end{array}$ \\
\hline k. $924 \mathrm{v}-925 \mathrm{v}$ & dok. b.m.r. [dot. szpitala w Warężu] \\
\hline k. 929-932 & $\begin{array}{l}\text { dok. } 1698 \text { [pol.], } 1670 \text { [pol.], } 1680 \text { [pol.], } 1680 \text { [pol.], b.m.r. [pol.], } 1691 \text { [pol.] } \\
\text { [dot. uposażenia parafii w Warężu] }\end{array}$ \\
\hline k. $933-947 \mathrm{v}$ & Dub \\
\hline k. $933 \mathrm{v}-936$ & $\begin{array}{l}\text { Skierbieszów, } 21 \text { V } 1544 \\
\text { Biskup chełmski Jan Dziaduski eryguje parafię w Dubie na podstawie fundacji } \\
\text { Dobrogosta Dubieńskiego vel Drohiczyńskiego [oblata w aktach grodzkich beł- } \\
\text { skich, 1638] }\end{array}$ \\
\hline k. $936-937$ & dok. 1638 [dot. bractwa różańcowego] \\
\hline k. $937-940$ & $\begin{array}{l}\text { Dub, } 20 \text { IV } 1638 \\
\text { Aleksander Myszkowski, starosta tyszowiecki odnawia i powiększa uposażenie } \\
\text { kościoła parafialnego w Dubie }\end{array}$ \\
\hline k. $940-942$ & dok. 1643 [dot. uposażenia parafii] \\
\hline k. $948-957$ & m Grabowiec \\
\hline k. $948-950 v$ & $\begin{array}{l}\text { Chełm, } 3 \text { VIII } 1431 \\
\text { Jan, biskup chełmski potwierdza w transumpcie fundację kościoła parafialnego } \\
\text { w Grabowcu dokonaną przez ks. Siemowita księcia płockiego i bełskiego, Beł, } \\
2 \text { II } 1394 \text { [wyd. ZDM IV, s. 324-326] }\end{array}$ \\
\hline k. $958-972$ & m Sokal [prawa i przywileje] \\
\hline k. $958-960$ & $\begin{array}{l}\text { Połock, } 24 \text { VIII } 1517 \\
\text { Zygmunt Stary potwierdza zamianę dóbr między Janem Dobraczyńskim, pleba- } \\
\text { nem w Sokalu a Jerzym Krupskim, kasztelanem lwowskim [trans. Zygmunta III, } \\
\text { Warszawa, } 11 \text { VI } 1627 \text {, trans. Jana Kazimierza, Lwów, } 12 \times 1662 \text { ] }\end{array}$ \\
\hline
\end{tabular}




\begin{tabular}{|l|l|}
\hline k. 960-972 & $\begin{array}{l}\text { dok. 1627, 1661, 1676, 1670, 1641, 1644, 1656, 1660, 1668, 1682, 1659, 1662 } \\
\text { [dot. uposażenia parafii Sokal], 1660 [wyciąg z testamentu Jana Kłopotowskiego, } \\
\text { rotmistrza królewskiego, pol.], 1667 [wyciąg z testamentu Franciszka Kochanow- } \\
\text { skiego, pol.] }\end{array}$ \\
\hline m Sokal, brygidki \\
\hline k. 972v & $\begin{array}{l}\text { Nomina et cognomina sanctimonialium conventus Sokaliensis ordinis sanctae } \\
\text { Brigittae sub tempus visitationis personalis eiusdem conventus per ipsummet illu- } \\
\text { strissimum et reverendissimum dominum Christophorum Szembek episcopum } \\
\text { Chełmensem [list zakonnic klasztoru brygidek w Sokalu] }\end{array}$ \\
\hline k. 974-978 & $\begin{array}{l}\text { dok.1664[testamentJanaChmieleckiego,kanonikakatedralnegochełmskiegoipro- } \\
\text { boszcza w Sokalu, pol.] }\end{array}$ \\
\hline k. 980-981v & dok. 1667 [testament Franciszka Kochanowskiego, pol.] \\
\hline k. 982-988 & Płonka \\
\hline k. 982-984v & $\begin{array}{l}\text { Skierbieszów, 1 XII 1525 } \\
\text { Biskup Jakub Buczacki inkorporuje do kolegium wikariuszy katedralnych parafie } \\
\text { Krasnystaw i Płonka w diecezji chełmskiej oraz parafię Parczew w diecezji kra- } \\
\text { kowskiej [trans. Zygmunta I, Kraków, 26 I 1527, zob. k. 75-78v] }\end{array}$ \\
\hline k. 984v-985V & dok. 1714 [pol.] [dot. uposażenia parafii w Płonce] \\
\hline k. 988v-1007v & $\begin{array}{l}\text { Chłaniów [m.in. inwentarzplebaniiz1701 r.,inwentarzidekretreformacyjnyz1715 } \\
\text { r.] }\end{array}$ \\
\hline k. 1003v-1006 & $\begin{array}{l}\text { Szczebrzeszyn, 22 IX 1419 } \\
\text { Jan, biskup chełmski, eryguje kościół parafialny w Chłaniowie na podstawie fun- } \\
\text { dacji dziedziców Goworki, Manczyny i Mikołaja [oblata w aktach ziemskich } \\
\text { krasnostawskich, 1 II 1599; wyd. ZDM V, s. 223-225] }\end{array}$ \\
\hline k. 1006-1010v & dok. 1710 [dot. uposażenia parafii w Chłaniowie] \\
\hline k. 998-1002v & Mokre Lipie \\
\hline
\end{tabular}

\section{Archiwum Archidiecezjalne w Lublinie Rep60 A153 - ABMK 2370}

I. Actorum visitationis generalis omnium totius dioecesis Chełmensis ecclesiarum, quam illustrissimus et reverendissimus dominus dominus Christophorus Ioannes in Słupow Szembek episcopus Chełmensis, praepositus generalis Miechoviensis in persona propria perfecit. Volumen 2. in quo privilegia ac iura praecipua et principaliora singularum ecclesiarum ex suis originalibus et authenticis descripta, tum status modernus et inventaria post factam prius omnium ac singulorum revisionem et verificationem, decretaque reformationis pro qualibet ecclesia lata et publicata et nonnulla alia ad dioecesim ecclesiam cathedralem et alias spectantia continentur ad laudem Dei Omnipotentis et futuram ecclesiarum utilitatem opera, studio et cura perillustris et admodum reverendi domini Michaelis in Piechowice Piechowski iuris utriusque licentiati ecclesiarum cathedralis Chełmensis canonici et collegiatae insignis Visliciensis praepositi, Scarbimiriensis canonici et causarum curiae episcopalis Chełmensis auditoris generalis et iudicis consummatum in fine anni Domini 1718. 
II. Wizytacja zewnętrzna. Czystopis.

Format: $33,5 \times 21,5 \mathrm{~cm}$

k. $629+$ knlb: 1-8 (na początku księgi), 18 ${ }^{\mathrm{a}}-18^{\mathrm{b}}, 26^{\mathrm{a}}, 35^{\mathrm{a}}, 67^{\mathrm{a}}-67^{\mathrm{b}}, 86^{\mathrm{a}}, 95^{\mathrm{a}}-95^{\mathrm{r}}$ (wklejone druki), 234 $4^{\mathrm{a}}, 236^{\mathrm{a}}, 452^{\mathrm{a}}-452^{\mathrm{b}}$ (w części o powtórnej foliacji), 511 ${ }^{\mathrm{a}}-511^{\mathrm{f}}$, $514^{\mathrm{a}}-514^{\mathrm{d}}, 515^{\mathrm{a}}-515^{\mathrm{n}}, 533^{\mathrm{a}}-533^{\mathrm{g}}, 539^{\mathrm{a}}-539^{\mathrm{h}}, 608^{\mathrm{a}}, 619^{\mathrm{a}}, 629^{\mathrm{a}}-629^{\mathrm{d}}$; brak k. $22,238-$ 239, 459 -460a $, 475^{\text {a }}, 521$; k. niezapisane: knlb. 2-4, 28, 35a $, 69,154-155,202$, $237,272-274,475,474^{\mathrm{a}}, 514^{\mathrm{e}}-514^{\mathrm{f}}, 515^{\circ}, 522,534,549,629 \mathrm{v}-629^{\mathrm{d}} \mathrm{v}$; podwójna foliacja kart: $449-478 \mathrm{v}$.

\begin{tabular}{|c|c|}
\hline knlb. 1 & [tytuł: Księga V. Visitationes anno 1675] \\
\hline knlb. $4 \mathrm{v}$ & [spis treści księgi] \\
\hline knlb. 5 & [strona tytułowa] \\
\hline knlb. $6-8 \mathrm{v}$ & [spis treści księgi] \\
\hline k. 1-2 & dok. 1713,1713 [brewe apostolskie do kleru diecezji chełmskiej] \\
\hline k. $3-22 v$ & $\begin{array}{l}\text { dok. 1713, } 1713 \text { [pol.], } 1715 \text { [pol.], } 1715 \text { [pol.], 1715, 1715, } 1715 \text { [pol.], 1716, } \\
\text { 1717, 1717, 1717, 1717, 1717, 1718, } 1718 \text { [pol.], 1718, 1718, 1718, } 1719 \text { [pol.] } \\
\text { [obwieszczenia i zarządzenia «processus» biskupa chełmskiego Krzysztofa Szem- } \\
\text { beka] }\end{array}$ \\
\hline k. $23-41 v$ & m Krasnystaw \\
\hline k. $23-26 v$ & dok. $1717,1718,1718$ [dot. relacji o stanie diecezji chełmskiej z 1717 r.] \\
\hline k. $27-27 \mathrm{v}$ & [powinności miasteczka Pawłowa] \\
\hline k. 29-31 & [spis wyposażenia ruchomego katedry w Krasnymstawie, pol.] \\
\hline k. 32-33 & $\begin{array}{l}\text { [dekret reformacyjny z wizytacji biskupa Łubieńskiego, I połowa XVII wieku, } \\
\text { dot. kolegium wikariuszy katedralnych] }\end{array}$ \\
\hline k. 34-36 & $\begin{array}{l}\text { dok. 1673, 1679, } 1690 \text { [dot. instytucji dla Jana Ochowicza, na wikarię katedralną, } \\
\text { prebendę św. Anny w Krasnymstawie i kanonię honorową] }\end{array}$ \\
\hline k. $37-38$ & [opis kolegium wikariuszy katedralnych] \\
\hline k. $39-40$ & $\begin{array}{l}\text { Kumów, } 5 \times 1663 \\
\text { Tomasz Leżeński, biskup chełmski, eryguje beneficjum kapelana św. Anny w koś- } \\
\text { ciele katedralnym w Krasnymstawie i potwierdza w transumpcie dokument fun- } \\
\text { dacyjny Mikołaja Świrskiego, Krasnystaw, } 30 \text { I } 1649 \text { [zob. AKL. Rep } 60 \text { A152, k. } \\
\text { 163-165] }\end{array}$ \\
\hline k. $41-41 \mathrm{v}$ & [opis kaplicy św. Anny] \\
\hline k. $42-67 \mathrm{~V}$ & m Grabowiec [m.in. prawa i przywileje] \\
\hline k. $42-45 \mathrm{v}$ & $\begin{array}{l}\text { Chełm, } 3 \text { VIII } 1431 \\
\text { Jan, biskup chełmski potwierdza w transumpcie fundację kościoła parafialnego } \\
\text { w Grabowcu dokonaną przez ks. Siemowita księcia płockiego i bełskiego, Beł, } \\
2 \text { II } 1394 \text { [wyd. ZDM IV, s. 274-277; ZDM V, s. 324-326, zob. AKL. Rep60 A152, } \\
\text { k. 948-950v] }\end{array}$ \\
\hline k. $45 \mathrm{v}-46 \mathrm{v}$ & $\begin{array}{l}\text { Krasnystaw, } 21 \text { I } 1557 \\
\text { Jakub Uchański, biskup chełmski zezwala plebanom grabowieckim na spuszcza- } \\
\text { nie wody ze swojego stawu w Cieszynie przez cztery tygodnie w roku }\end{array}$ \\
\hline
\end{tabular}




\begin{tabular}{|c|c|}
\hline k. $47 \mathrm{v}-48 \mathrm{v}$ & $\begin{array}{l}\text { Warszawa, } 26 \text { II } 1622 \\
\text { Zygmunt III powiększa uposażenie kapituły katedralnej w Krasnymstawie przez } \\
\text { inkorporację parafii w Grabowcu wraz z jej uposażeniem [wyd. B. Szady, dz. cyt., } \\
\text { s. 140-142; oblata w Krasnymstawie } 7 \text { VI 1634; zob. AKL. Rep60 A152, k. 50v- } \\
\text { 51v] }\end{array}$ \\
\hline k. $48 \mathrm{v}-51 \mathrm{v}$ & $\begin{array}{l}\text { Krasnystaw, } 24 \text { V } 1627 \\
\text { Maciej Łubieński, biskup chełmski potwierdza inkorporację parafii w Grabowcu } \\
\text { do kapituły katedralnej w Krasnymstawie oraz określa obowiązki i uposażenie } \\
\text { kapituły i komendariusza [wyd. B. Szady, dz. cyt., s. 142-145; oblata w Krasnym- } \\
\text { stawie } 7 \text { VI 1634; zob. AKL. Rep60 A152, k. 52-54] }\end{array}$ \\
\hline k. $51 \mathrm{v}-54$ & dok. 1626,1715 [dot. obsady parafii w Grabowcu] \\
\hline k. $67 \mathrm{v}-68 \mathrm{v}$ & m Tyszowce [dekret reformacyjny] \\
\hline k. $67^{\mathrm{a}}-67^{\mathrm{a}} \mathrm{v}$ & Bończa \\
\hline k. $67^{\mathrm{a}} \mathrm{v}-67^{\mathrm{b}}$ & Gorzków \\
\hline k. $67^{\mathrm{b}}-67^{\mathrm{b}} \mathrm{v}$ & Surhów \\
\hline k. $70-85 \mathrm{v}$ & m Grabowiec \\
\hline k. $70-85 \mathrm{v}$ & $\begin{array}{l}\text { dok. } 1716 \text { [pol.], } 1716 \text { [pol.], } 1716 \text { [pol.] [dot. stanu kościoła w Grabowcu, opis } \\
\text { szkód dokonanych przez wojska saskie w czasie konfederacji tarnogrodzkiej, } \\
\text { pol.] }\end{array}$ \\
\hline k. $86-90 v$ & m Mosty \\
\hline k. $86-90 v$ & $\begin{array}{l}\text { dok. 1716, } 1716 \text { [pol.] [w sprawie morderstwa plebana w Mostach w czasie kon- } \\
\text { federacji tarnogordzkiej] }\end{array}$ \\
\hline k. 91-95 & $\begin{array}{l}\text { dok. 1716, 1716, } 1716 \text { [dot. konfederacji tarnogrodzkiej i szkód w Grabowcu i Mo- } \\
\text { stach] }\end{array}$ \\
\hline k. $95^{\mathrm{a}}-95^{\mathrm{r}} \mathrm{V}$ & $\begin{array}{l}\text { Relatio coronationis Thaumaturgae Claro-Montanae in Regno Poloniae [druk. } \\
\text { łac., w części po włosku] }\end{array}$ \\
\hline k. $96-107 \mathrm{v}$ & Wożuczyn \\
\hline k. 96-98 & $\begin{array}{l}\text { Kumów, } 18 \text { VIII } 1595 \\
\text { Stanisław Gomoliński, biskup chełmski, potwierdza w transumpcie odnowienie } \\
\text { fundacji parafii w Wożuczynie dokonane przez Jakuba Wożuczyńskiego, wojskie- } \\
\text { go bełskiego, Wożuczyn, } 19 \text { VII } 1595 \text { r. [oblata w aktach ziemskich grabowie- } \\
\text { ckich, } 30 \times 1595 \text { ] }\end{array}$ \\
\hline k. $98 \mathrm{v}-100$ & dok. 1636, 1691 [pol.] [dot. uposażenia parafii w Wożuczynie] \\
\hline k. $107 \mathrm{v}-117 \mathrm{v}$ & Dzierążnia \\
\hline k. $110-111 \mathrm{v}$ & $\begin{array}{l}\text { Dzierążnia, } 30 \text { III } 1537 \\
\text { Stanisław, Tyburcjusz i Maciej Dzierążyńscy uposażają parafię w Dzierążni }\end{array}$ \\
\hline k. $111 \mathrm{v}$ & $\begin{array}{l}\text { Sawin, } 7 \text { IV } 1537 \\
\text { Jakub Buczacki, biskup chełmski potwierdza fundację parafii w Dzierążni doko- } \\
\text { naną przez Stanisława, Tyburcjusza i Macieja Dzierążyńskich }\end{array}$ \\
\hline k. $112-113 v$ & dok. 1671, 1675 [pol.] [dot. uposażenia parafii w Dzierążni] \\
\hline k. $118-139 \mathrm{v}$ & m Rachanie \\
\hline k. $119-128$ & $\begin{array}{l}\text { dok. 1694, 1700, } 1614 \text { [pol.], } 1644 \text { [pol.], 1704, 1604, 1663, } 1701 \text { [pol.], } 1702 \\
\text { [pol.], 1702, } 1702 \text { [pol.] [dot. uposażenia i wyposażenia parafii Rachanie] }\end{array}$ \\
\hline k. $129-130$ & $\begin{array}{l}\text { dok. } 1692 \text { [pol.], } 1695 \text { [pol.], 1690, } 1705 \text { [pol.], } 1691 \text { [dot. uposażenia i wyposa- } \\
\text { żenia parafii Rachanie] }\end{array}$ \\
\hline k. $140-153 \mathrm{v}$ & Nabróż \\
\hline
\end{tabular}




\begin{tabular}{|c|c|}
\hline k. $140-141$ & $\begin{array}{l}\text { Nabróż, } 15 \text { XI } 1411 \\
\text { Jan Sąpnik wraz z żoną swą Agnieszką uposażają kościół parafialny we wsi Na- } \\
\text { bróż [oblata w aktach ziemskich bełskich, } 8 \text { I 1596; wyd. ZDM V, s. 121-123] }\end{array}$ \\
\hline k. $141-141 v$ & $\begin{array}{l}\text { Nabróż, } 19 \text { XII } 1470 \\
\text { Paweł z Grabowa, biskup chełmski na prośbę Macieja, plebana w Nabrożu po- } \\
\text { twierdza fundację kościoła parafialnego w Nabrożu }\end{array}$ \\
\hline k. $147-151$ & dok. 1711 [pol.], 1711, 1717 [dot. uposażenia wikariusza parafii w Nabrożu] \\
\hline k. $152 \mathrm{v}-153 \mathrm{v}$ & dok. 1630, 1717 [dot. uposażenia parafii w Nabrożu] \\
\hline k. $155 \mathrm{v}-183 \mathrm{v}$ & Gródek \\
\hline k. 156-157 & $\begin{array}{l}\text { Gródek, } 24 \text { II } 1409 \\
\text { Wołczko z Gródka, Wojciech ze Szlatyna, Stefan z Wereszczycy, Stanisław z Ty- } \\
\text { pina i Mikołaj z Podhorzec uposażają kościół parafialny w Gródku [wyd. ZDM V, } \\
\text { s. 92-94; oblata w aktach biskupa chełmskiego, } 28 \times 1614 \text { ] }\end{array}$ \\
\hline k. $157-158$ & $\begin{array}{l}\text { Chełm, } 13 \text { VI } 1420 \\
\text { Jan biskup chełmski eryguje kościół parafialny w Gródku potwierdzając nadania } \\
\text { fundatorów Wołczka z Gródka, Wojciecha ze Szlatyna, Stefana z Wereszczycy, } \\
\text { Stanisława z Typina i Mikołaja z Podhorzec [wyd. ZDM II, s. 87-89; oblata w ak- } \\
\text { tach biskupa chełmskiego, } 28 \times 1614 \text { ] }\end{array}$ \\
\hline k. $158-158 \mathrm{v}$ & $\begin{array}{l}\text { Bełz, } 12 \text { I } 1540 \\
\text { Jan i Mikołaj Russianowie, dziedzice w Gródku, nadają kościołowi parafialnemu } \\
\text { w Gródku staw zwany Jeżówka }\end{array}$ \\
\hline k. $158-177$ & $\begin{array}{l}\text { dok. } 1644 \text { [pol.], 1689, 1689, 1690, 1602, } 1693 \text { [pol.], 1699, 1700, } 1693 \text { [pol.], } \\
1693 \text { [pol.], 1603, 1604, } 1710 \text { [pol.], } 1711 \text { [pol.], } 1694 \text { [pol.], 1636, 1712, 1650, } \\
1671 \text { [pol. testament Anety Rudowskiej], 1691, } 1690 \text { [dot. uposażenia parafi } \\
\text { w Gródku] }\end{array}$ \\
\hline k. $184-191 \mathrm{v}$ & m Belz \\
\hline k. $189-190$ & $\begin{array}{l}\text { Bełz, } 6 \text { II } 1593 \\
\text { Zeznanie szlachty i mieszczan bełskich w sprawie historii i majątku kościoła pa- } \\
\text { rafialnego w Bełzie }\end{array}$ \\
\hline k. $190 \mathrm{v}-191 \mathrm{v}$ & dok. 1713 [dot. uposażenia parafii w Bełzie] \\
\hline k. $193 \mathrm{v}-194$ & Chodywańce [dekret reformacyjny] \\
\hline k. $194-196 \mathrm{v}$ & m Laszczówka \\
\hline k. $197-216$ & m Bełz, kłs. \\
\hline k. $200-201 v$ & $\begin{array}{l}\text { Warszawa, } 8 \text { VII } 1619 \\
\text { Zygmunt III Waza potwierdza w transumpcie odnowienie fundacji prepozytury } \\
\text { szpitalnej w Bełzie dokonane przez Jerzego Zamoyskiego, biskupa chełmskiego, } \\
\text { Skierbieszów, } 17 \text { V } 1619 \text { [oblata w aktach ziemskich bełskich, } 13 \text { I 1620] }\end{array}$ \\
\hline k. 203-205 & dok. 1623 [dot. fundacji prebendy altarzysty w kościele szpitalnym w Bełzie] \\
\hline k. $205 \mathrm{v}-207$ & dok. 1708 [pol.], 1711, [dot. uposażenia prepozytury szpitalnej w Bełzie] \\
\hline k. $208-208 v$ & dok. 1626 [dot. bractwa Męki Pańskiej w kościele szpitalnym w Bełzie] \\
\hline k. $209-210 v$ & $\begin{array}{l}\text { dok. } 1634,1634 \text { [dot. uposażenia kantora i organisty przy parafii i prepozyturze } \\
\text { szpitalnej w Bełzie] }\end{array}$ \\
\hline k. $210 v-215$ & $\begin{array}{l}\text { dok. } 1697,1650,1632,1639,1602,1623,1707 \text { [pol.], } 1711 \text { [pol.] [dot. uposaże- } \\
\text { nia prepozytury i altarii w kościele szpitalnym w Bełzie] }\end{array}$ \\
\hline k. $217-227 \mathrm{v}$ & Trzeszczany [m.in. fragmenty wizytacji z 1603, 1635 i 1672 r.] \\
\hline k. $218-227 \mathrm{v}$ & $\begin{array}{l}\text { dok. } 1608,1612,1637 \text { [pol.] } 1664,1665,1703,1706, \text { b.d [pol.] [dot. uposażenia } \\
\text { parafii w Trzeszczanach] }\end{array}$ \\
\hline
\end{tabular}




\begin{tabular}{|c|c|}
\hline k. $228-234 \mathrm{v}$ & m Skierbieszów \\
\hline k. $234-234 v$ & $\begin{array}{l}\text { Skierbieszów, } 20 \text { VIII } 1579 \\
\text { Adam Pilchowski, biskup chełmski przyznaje cerkwi greckiej w Skierbieszowie } \\
\text { osep z dwóch łanów w Skierbieszowie }\end{array}$ \\
\hline k. $235-236$ & m Grabowiec \\
\hline k. $235-236$ & dok. 1715 [dot. wyposażenia i uposażenia parafii w Grabowcu] \\
\hline k. $238-238 v$ & m Orchów \\
\hline k. $239-271$ & Sosnowica \\
\hline k. $246-248$ & $\begin{array}{l}\text { Sosnowica, } 16 \text { III } 1678 \\
\text { Wojciech Rostkowski pleban w Kumowie i Kazimierz Blinowski pleban w Ol- } \\
\text { chowcu z polecenia biskupa chełmskiego opisują stan kościoła i majątku funda- } \\
\text { cyjnego parafii w Sosnowicy [„,Commissio pro fundatione”]. }\end{array}$ \\
\hline k. $248-253$ & $\begin{array}{l}\text { Skierbieszów, } 31 \text { I } 1685 \\
\text { Stanisław Święcicki, biskup chełmski eryguje parafię w Sosnowicy i potwierdza } \\
\text { w transumpcie dokument fundacyjny Katarzyny z Zamiechowa Sosnowskiej, } \\
\text { Krasnystaw, } 19 \text { IV } 1678\end{array}$ \\
\hline k. $253-270 v$ & $\begin{array}{l}\text { dok. 1696, } 1715 \text { [pol.], 1715, 1687, } 1686 \text { [pol.], 1682, } 1685 \text { [pol.], } 1687 \text { [pol.], } \\
1688 \text { [pol.], 1691, 1681, 1687, } 1688 \text { [pol.], 1685, } 1685 \text { [pol.], } 1693 \text { [pol.], } 1687 \\
\text { [pol.], } 1685 \text { [pol.], 1685 [pol.], } 1708 \text { [pol.], } 1714 \text { [pol.], } 1715 \text { [pol.], } 1713 \text { [dot. } \\
\text { fundacji i uposażenia parafii w Sosnowicy] }\end{array}$ \\
\hline k. $275-317$ & m Potylicz \\
\hline k. $275-281 v$ & $\begin{array}{l}\text { Bełz, } 4 \text { VI } 1423 \\
\text { Siemowit książę Mazowsza uposaża kościół parafialny w mieście Potyliczu [ob- } \\
\text { lata w aktach oficjała chełmskiego } 15 \text { III 1574; oblata w konsystorzu lwowskim } \\
20 \text { III 1600; trans. Zygmunta III, Warszawa, 15 IV 1600; potw. przez Pawła bisku- } \\
\text { pa chełmskiego, Potylicz, } 28 \text { I 1499 [datacja watpliwa]; potw. przez Piotra Twar- } \\
\text { dochleba burmistrza oraz rajców Potylicza, Potylicz, 15 VIII 1550] }\end{array}$ \\
\hline k. $281 v-295$ & $\begin{array}{l}\text { dok. 1600, 1600, } 1600 \text { [pol.], 1614, 1615, } 1615 \text { [pol.], 1616, 1614, 1617, 1618, } \\
1619,1614,1622 \text { [pol.], [dot. uposażenia parafii w Potyliczu] }\end{array}$ \\
\hline k. 295-298 & $\begin{array}{l}\text { Kumów, } 10 \text { III } 1629 \\
\text { Remigiusz Koniecpolski, biskup chełmski, podnosi parafię w Potyliczu do rangi } \\
\text { prepozytury }\end{array}$ \\
\hline k. 298-299 & $\begin{array}{l}\text { Warszawa, } 20 \text { IV } 1629 \\
\text { Zygmunt III Waza, król i patron parafii w Potyliczu, potwierdza przekształcenie } \\
\text { tej parafii w prepozyturę }\end{array}$ \\
\hline k. $299-307 \mathrm{v}$ & $\begin{array}{l}\text { dok. } 1628 \text { [testament Jana Lachowicza], } 1627 \text { [dot. uposażenia parafii w Potyli- } \\
\text { czu] }\end{array}$ \\
\hline k. $317 \mathrm{v}-323$ & m Rawa \\
\hline k. $317 \mathrm{v}-318$ & dok. 1629,1655 [dot. uposażenia parafii w Rawie] \\
\hline k. $319-320 v$ & $\begin{array}{l}\text { dok. 1708, } 1686 \text { [pol.], } 1705 \text { [pol.], } 1691 \text { [pol.] [dot. uposażenia i wyposażenia } \\
\text { parafii w Rawie oraz bractwa różańcowego] }\end{array}$ \\
\hline k. $321-321 v$ & dok. 1717 [interdykt dot. kaplicy w Horyńcu] \\
\hline k. $324-336 v$ & m Magierów \\
\hline k. $326-327 v$ & $\begin{array}{l}\text { Magierów, } 25 \text { VIII } 1595 \\
\text { Jan Bełżecki, dziedzic Magierowa funduje parafię w swoim mieście [oblata w ak- } \\
\text { tach grodzkich bełskich, } 30 \text { VI 1597] }\end{array}$ \\
\hline
\end{tabular}




\begin{tabular}{|c|c|}
\hline k. $327 v-329$ & $\begin{array}{l}\text { dok. 1649, 1641, 1650, } 1699 \text { [pol., zapisy testamentowe Anny z Niszczyckich } \\
\text { Bełżeckiej, Zofii z Bełżeckich i Stanisława Głogowskich] oraz Kazimierza Gło- } \\
\text { gowskiego] }\end{array}$ \\
\hline k. $329 v-334$ & $\begin{array}{l}\text { dok. } 1637,1637,1717 \text { [pol.], } 1717 \text { [pol.], } 1715 \text { [pol.] [dot. uposażenia i inwenta- } \\
\text { rza parafii w Magierowie] }\end{array}$ \\
\hline k. $334 v-335$ & $\begin{array}{l}\text { Ruda Magierowska, } 22 \text { III } 1696 \\
\text { Samuel z Głogowca Głogowski, cześnik nowogródzki, uposaża prebendę altarzy- } \\
\text { sty przy kościele parafialnym w Magierowie }\end{array}$ \\
\hline k. $336 \mathrm{v}-338 \mathrm{v}$ & m Potylicz [dekret reformacyjny, zob. k. 314-317] \\
\hline k. $339-350 v$ & m Uhnów \\
\hline k. $340 v-341 v$ & $\begin{array}{l}\text { Sącz, } 5 \text { IX } 1474 \\
\text { Marek, legat apostolski, potwierdza w transumpcie dokument fundacyjny parafii } \\
\text { w Uhnowie wystawiony przez Zygmunta Radzanowskiego, wojewodę bełskiego } \\
\text { (Uhnów, } 7 \text { I 1470) }\end{array}$ \\
\hline k. $342-342 v$ & $\begin{array}{l}\text { Rzeczki, } 13 \times 1595 \\
\text { Wawrzyniec z Trzciany Trzciński, kasztelan lubaczowski powiększa uposażenie } \\
\text { parafii w Uhnowie [pol., oblata w konsystorzu lwowskim } 17 \times 1597 \text { ] }\end{array}$ \\
\hline k. $342 v-345 v$ & $\begin{array}{l}\text { dok. 1601, 1698, 1668, } 1706 \text { [pol.], } 1712 \text { [pol.], } 1714 \text { [dot. uposażenia parafii } \\
\text { w Uhnowie] }\end{array}$ \\
\hline k. $345 v-346 v$ & $\begin{array}{l}\text { Bełz, } 18 \text { V } 1697 \\
\text { Marianna Zaborowska, wdowa po Krzysztofie Dunin, kasztelanie lubaczowskim } \\
\text { uposaża beneficjum dla promotora bractwa różańcowego przy parafii w Uhnowie } \\
\text { [potw. przez Konstantego Czulskiego, oficjała chełmskiego, Krasnystaw, } 17 \text { VI } \\
\text { 1697] }\end{array}$ \\
\hline k. $347-349$ & $\begin{array}{l}\text { dok. 1666, 1696, 1704, } 1697 \text { [pol.], } 1699 \text { [dot. Bractwa różańcowego i szpitala } \\
\text { w Uhnowie] }\end{array}$ \\
\hline k. 351-429 & m Tomaszów [k. 371v-429 dot. bractwa różańcowego] \\
\hline k. $355 \mathrm{v}-359 \mathrm{v}$ & $\begin{array}{l}\text { Kumów, } 7 \text { V } 1627 \\
\text { Maciej Łubieński, biskup chełmski potwierdza w transumpcie dokument funda- } \\
\text { cyjny parafii w Tomaszowie wystawiony przez ordynata Tomasza Zamoyskiego, } \\
\text { wojewodę kijowskiego (Zamość, } 20 \text { IV 1627) }\end{array}$ \\
\hline k. $360-367 v$ & $\begin{array}{l}\text { dok. } 1666,1686 \text { [pol.], 1686, } 1639 \text { [pol.], } 1639 \text { [pol.], } 1667 \text { [dot. uposażenia pa- } \\
\text { rafii w Tomaszowie] }\end{array}$ \\
\hline k. $371 v-372 v$ & dok. 1717 [dot. uposażenia bractwa różańcowego w Tomaszowie] \\
\hline k. $373-377$ & $\begin{array}{l}\text { Skierbieszów, } 13 \text { XI } 1699 \\
\text { Mikołaj Michał Wyżycki, biskup chełmski eryguje bractwo różańcowe oraz bene- } \\
\text { ficjum promotora przy parafii w Tomaszowie na podstawie fundacji mieszczan } \\
\text { tomaszowskich }\end{array}$ \\
\hline k. $377 v-408 v$ & $\begin{array}{l}\text { dok. 1703, } 1648 \text { [testament Jana Filewicza, pol.], } 1649 \text { [testament Jana Postrzega- } \\
\text { cza, pol.], } 1672 \text { [testament Reginy Wawrzyńcowej Poniatowczykowej, pol.], } 1700 \\
\text { pol.], } 1699 \text { [pol.], } 1609 \text { [data wattpliwa, testament Macieja Kawy, pol.], } 1690 \\
\text { [pol.], } 1699,1695 \text { [pol.], } 1700 \text { [pol.], 1690, b.d. [testament Jana Kubicza, pol.], } \\
1670,1690 \text { [pol.], 1691 [pol.], } 1664 \text { [pol.], } 1667 \text { [pol.], 1690, } 1651 \text { [testament } \\
\text { Jana Podobieńczyka i jego żony, pol.], 1654 [testament Jędrzeja Wieteszki, pol.], } \\
1649 \text { [testament Stanisława Guńczyka, pol.], } 1633 \text { [?] [pol.], 1661 [pol.], 1664 } \\
\text { [pol.], } 1699 \text { [pol.], } 1653 \text { [pol.], } 1651 \text { [pol.], } 1661 \text { [pol.], 1663 [pol.] }\end{array}$ \\
\hline
\end{tabular}




\begin{tabular}{|c|c|}
\hline k. $417 \mathrm{v}-424$ & $\begin{array}{l}\text { dok. } 1650 \text { [pol.], } 1708 \text { [pol.], } 1711 \text { [pol.], 1688, } 1673 \text { [pol.], } 1681 \text { [pol.], } 1694 \\
\text { [pol.], } 1713 \text { [pol.] [dot. bractwa różańcowego w Tomaszowie] }\end{array}$ \\
\hline k. 430-471 & m Tomaszów „,na Piaskach”, fil. \\
\hline k. $431 \mathrm{v}-437$ & $\begin{array}{l}\text { Lublin, } 19 \text { V } 1684 \\
\text { Stanisław Jacek Święcicki eryguje oraz potwierdza w transumpcie fundację pro-- } \\
\text { motorii bractwa szkaplerznego dokonaną przez Jana Kazimierza Brodeckiego } \\
\text { wraz z żoną Anną z Zawadzkich (Bełz, } 8 \text { IV 1684) }\end{array}$ \\
\hline k. $437 \mathrm{v}-447 \mathrm{v}$ & $\begin{array}{l}\text { dok. 1684, 1696, } 1711 \text { [pol.], } 1713 \text { [pol.], } 1711 \text { [pol.], } 1709 \text { [pol.], } 1712 \text { [pol.], } \\
1712 \text { [pol.] [dot. uposażenia kościoła „,na Piaskach” i miejscowego bractwa szka- } \\
\text { plerznego] }\end{array}$ \\
\hline k. $447 \mathrm{v}-448 \mathrm{v}$ & $\begin{array}{l}\text { Żerniki, } 1 \text { VI } 1709 \\
\text { Wojciech Antoni Wysocki, pleban żernicki uposaża altarię św. Wojciecha przy } \\
\text { kościele „na Piaskach” }\end{array}$ \\
\hline k. $448 \mathrm{v}-457$ & $\begin{array}{l}\text { dok. } 1709 \text { [pol.], } 1709 \text { [pol.], 1709, 1709, } 1709 \text { [pol.], } 1712 \text { [pol.] [dot. uposaże- } \\
\text { nia altarii św. Wojciecha przy kościele „na Piaskach”] }\end{array}$ \\
\hline k. $457-460 \mathrm{v}$ & $\begin{array}{l}\text { Krasnystaw, } 26 \text { VI } 1709 \\
\text { Walenty Konstanty Czulski, oficjał chełmski eryguje oraz potwierdza w tran- } \\
\text { sumpcie fundację altarii przy kościele „na Piaskach” dokonaną przez Antoniego } \\
\text { Wysockiego, plebana żernickiego (Żerniki, } 1 \text { VI 1709) }\end{array}$ \\
\hline k. $472-458^{\mathrm{a}}$ & Narol, m Florianów, fil. \\
\hline k. 476-477 & dok. 1708 [testament k. Wojciecha Antoniego Wielońskiego] \\
\hline k. $452^{\mathrm{a}}$ & dok. 1717 [dot. uposażenia parafii w Narolu, pol.] \\
\hline k. $461^{\mathrm{a}}-469^{\mathrm{a}} \mathrm{V}$ & m Lipsko \\
\hline k. $461^{\mathrm{a}}-462^{\mathrm{a}} \mathrm{V}$ & $\begin{array}{l}\text { Lipsko, } 22 \text { IV } 1625 \\
\text { Andrzej Lipski, biskup włocławski i właściciel Lipska uposaża kościół parafialny } \\
\text { w swoim mieście [oblata w aktach ziemskich bełskich, } 1 \text { VII 1630] }\end{array}$ \\
\hline k. $470^{\mathrm{a}}-473^{\mathrm{a}}$ & m Plazów \\
\hline k. $476^{\mathrm{a}}-479$ & m Krasnobród [parafia zakonna, dominikanie] \\
\hline k. $476^{\mathrm{a}} \mathrm{v}-477^{\mathrm{a}}$ & $\begin{array}{l}\text { dok. } 1699 \text { [dot. poświęcenia kościoła], } 1679 \text { [dot. powierzenia zakonnikom dusz- } \\
\text { pasterstwa parafialnego], } 1673 \text { [dot. przekazania zboru luterańskiego w ręce do- } \\
\text { minikanów, pol.] }\end{array}$ \\
\hline k. $480-488 \mathrm{v}$ & m Turobin \\
\hline k. $485-488 \mathrm{v}$ & Czernięcin, fil. [opis w ramach parafii w Turobinie] \\
\hline k. $486-488 \mathrm{v}$ & m Turobin, kłs. [opis uposażenia w ramach parafii w Turobinie] \\
\hline k. $489-497 \mathrm{v}$ & Żółkiew \\
\hline k. $489-490$ & $\begin{array}{l}\text { Krasnystaw, } 31 \text { XII } 1622 \\
\text { Maciej Łubieński biskup chełmski potwierdza w transumpcie odnowienie funda- } \\
\text { cji parafii w Żółkiewce dokonane przez Jana, Adama, Łukasza, Idziego, Jana, } \\
\text { Mikołaja, Marka Żółkiewskich, dziedziców w Żółkwi (Źółkiew, } 4 \text { VIII 1609) [ob- } \\
\text { lata w aktach ziemskich krasnostawskich, } 22 \text { V 1623, } 31 \text { I 1628] }\end{array}$ \\
\hline k. $490-491 \mathrm{v}$ & dok. 1680 [dot. uposażenia kaplicy i szpitala w Żółkwi] \\
\hline k. 493-494 & dok. 1716 [testament Jana Falęckiego, stolnika nowogrodzkiego, pol.] \\
\hline k. 498-499 & m Bilgoraj \\
\hline k. 499 & dok. 1717 [dot. obsady parafii w Biłgoraju] \\
\hline k. $500-513$ & m Luboml \\
\hline
\end{tabular}




\begin{tabular}{|c|c|}
\hline k. $501 v-502 v$ & $\begin{array}{l}\text { Krasnystaw, } 21 \text { VIII } 1414 \text { r. } \\
\text { Król Władysław Jagiełło pomnaża uposażenie kościoła parafialnego w nowo za- } \\
\text { łożonym mieście Luboml, dokonane przed dwoma laty przez Hanka z Sandomie- } \\
\text { rza, wójta lubomelskiego i sekretarza królewskiego [falsyfikat, zob. ZDM VI, s. } \\
\text { 384-385] }\end{array}$ \\
\hline k. $502 \mathrm{v}-503$ & $\begin{array}{l}\text { Warszawa, } 20 \text { VIII } 1599 \\
\text { Król Zygmunt III Waza zapisuje } 22 \text { półwłóczki roli dla parafii w Lubomlu oraz } \\
\text { szpitali łacińskiego oraz rusińskiego w tym mieście }\end{array}$ \\
\hline k. $503 \mathrm{v}-504$ & dok. 1711 [dot. uposażenia parafii w Lubomlu] \\
\hline k. $506 \mathrm{v}-507$ & dok. 1677 [dot. uposażenia parafii w Lubomlu, pol.] \\
\hline k. $508 \mathrm{v}-509$ & dok. 1696 [dot. uposażenia promotorii bractwa w Lubomlu, pol.] \\
\hline k. $511^{\mathrm{a}}-511^{\mathrm{e}} \mathrm{V}$ & m Gorzków \\
\hline k. $511^{\mathrm{f}}-511^{\mathrm{f}} \mathrm{v}$ & Surhów [fragment wizytacji z 1711 r.] \\
\hline k. $514-514^{\mathrm{d}}$ & Moniatycze [inwentarz sprzętów] \\
\hline k. $515-516$ & Rzeplin \\
\hline k. $515-515^{\mathrm{m}} \mathrm{V}$ & $\begin{array}{l}\text { Bełz, } 7 \text { I } 1613 \\
\text { Andrzej Lipski, scholastyk krakowski i płocki, kustosz gnieźnieński oraz pleban } \\
\text { i dziedzic w Rzeplinie potwierdza przed aktami ziemskimi bełskimi doposażenie } \\
\text { parafii w Rzeplinie oraz fundację nowej prebendy przy tej parafii }\end{array}$ \\
\hline k. 518 & m Ratno [kontrola realizacji dekretów reformacyjnych] \\
\hline k. 518 & m Przewały [j.w.] \\
\hline k. $518-518 \mathrm{v}$ & m Korytnica [j.w.] \\
\hline k. $518 \mathrm{v}-519$ & m Dubienka [j.w.] \\
\hline k. $519 \mathrm{v}$ & m Opalin [j.w.] \\
\hline k. $519 \mathrm{v}$ & m Luboml [j.w.] \\
\hline k. $519 \mathrm{v}-520$ & m Maciejów [j.w.] \\
\hline k. $523-524$ & dok. 1673 [dot. kościołów w dekanacie Luboml, kongregacja dekanalna] \\
\hline k. $525-528$ & $\begin{array}{l}\text { Krasnystaw, } 17 \text { VII } 1671 \text { [błędnie, powinno być: } 1672 \text { ] } \\
\text { Krzysztof Żegocki, biskup chełmski, eryguje kolegium pijarów w Chełmie i in- } \\
\text { korporuje doń tamtejszą parafię, związaną z nią prebendę NMP oraz prepozyturę } \\
\text { szpitalną w Chełmie [zob. wyżej AKL. Rep60 A153, k. 616-618v] }\end{array}$ \\
\hline k. $528 \mathrm{v}-534$ & $\begin{array}{l}\text { dok. } 1667,1673,1672,1718,1718 \text { [pol.] [dot. uposażenia i erekcji kolegium pi- } \\
\text { jarów w Chełmie] }\end{array}$ \\
\hline k. $535-548 \mathrm{v}$ & Labunie \\
\hline k. $535-537$ & $\begin{array}{l}\text { Łabunie, } 8 \times 1435 \\
\text { Jan, biskup chełmski eryguje kościół parafialny w Łabuniach potwierdzając nada- } \\
\text { nie } 2 \text { łanów, } 3 \text { dworzyszcz, karczmy, łąki, dziesięcin i mesznego przez fundato- } \\
\text { rów Adama z Łabuń, Wawrzyńca z Komorowa i Erharda z Wierzby [potw. przez } \\
\text { Pawła Grabowskiego, biskupa chełmskiego, Łabunie, } 4 \text { II 1469; oblata w aktach } \\
\text { ziemskich grabowieckich, } 5 \text { XI 1612; wyd. ZDM II, s. 210-212] }\end{array}$ \\
\hline k. 537-541 & dok. 1640 [pol.], 1670 [dot. uposażenia parafii w Łabuniach] \\
\hline k. $541-542$ & dek. ref. z 23 XI 1700 \\
\hline k. $542-543 \mathrm{v}$ & dok. 1711 [dot. uposażenia parafii w Łabuniach] \\
\hline k. $550-565 \mathrm{v}$ & m Tyszowce \\
\hline
\end{tabular}




\begin{tabular}{|c|c|}
\hline k. $550 \mathrm{v}-551 \mathrm{v}$ & $\begin{array}{l}\text { Niepołomice, } 2 \text { VIII } 1549 \\
\text { Zygmunt August wyznacza komisję dla wyznaczenia uposażenia parafii w Ty- } \\
\text { szowcach [trans. Tyszowce, } 24 \text { III 1550; oblata w aktach ziemskich bełskich, } 13 \\
\text { I 1620] }\end{array}$ \\
\hline k. $554 \mathrm{v}-555$ & $\begin{array}{l}\text { Sokal, } 10 \text { III } 1550 \\
\text { Prokop Żółkiewski, kanonik chełmski i inni członkowie komisji wyznaczonej do } \\
\text { sprawy uposażenia parafii w Tyszowcach odsyłają do akceptacji królewskiej po- } \\
\text { stanowienie komisji i pozostawiają do rozstrzygnięcia królewskiego sprawę spor- } \\
\text { nego półłanka gruntu, } 6 \text { jazów i } 3 \text { łąk [trans. Tyszowce, } 24 \text { III 1550; oblata w ak- } \\
\text { tach ziemskich bełskich, } 13 \text { I 1620] }\end{array}$ \\
\hline k. $555-556 \mathrm{v}$ & $\begin{array}{l}\text { Parczew, } 7 \text { VIII } 1564 \\
\text { Zygmunt August, na prośbę plebana Stanisława, odnawia uposażenie parafii } \\
\text { w Tyszowcach }\end{array}$ \\
\hline k. $556 \mathrm{v}-557$ & dok. 1701 [pol.] [dot. uposażenia parafii w Tyszowcach] \\
\hline k. $566-606 \mathrm{v}$ & $\begin{array}{l}\text { Synodus dioecesana Chełmensis ab illustrissimo et reverendissimo domino Chri- } \\
\text { stophoro Ioanne in Słupow Szembek Dei et Apostolicae Sedis gratia episcopo } \\
\text { Chełmensi praeposito generali Miechoviensi Crasnostaviae in ecclesia cathedrali } \\
\text { praesente universo dioecesis clero celebrata die decima octava mensis iulii et aliis } \\
\text { duobus sequentibus diebus anno Domini } 1717 \text { [wyd. J. Sawicki, Concilia Polo- } \\
\text { niae. Źródta i studia krytyczne, t. 9: Synody diecezji chetmskiej obrzadku tacin- } \\
\text { skiego XVI-XVIII w. i ich statuty, Lublin 1957, s. 214-291. }\end{array}$ \\
\hline k. $607 \mathrm{v}$ & $\begin{array}{l}\text { Epistola pastoralis ad parochos provinciae Gnesnensis Bernardus Miseratione } \\
\text { Divina tituli sancti Ioannis ante etc. [sam nagłówek, bez treści] }\end{array}$ \\
\hline k. $608-627 \mathrm{v}$ & $\begin{array}{l}\text { Cornucopiae infulae Chełmensis usque ad quartum a fundato episcopatu Cheł- } \\
\text { mensi saeculum occlusum [zawiera biogramy biskupów chełmskich] }\end{array}$ \\
\hline k. $628-629$ & $\begin{array}{l}\text { [list okolicznościowy biskupa Krzysztofa Jana Szembeka z okazji koronacji obra- } \\
\text { zu Matki Boskiej Częstochowskiej, } 25 \text { VII 1718] }\end{array}$ \\
\hline
\end{tabular}




\title{
DIE VISITATIONEN DER DIÖZESE CULM (CHEŁMNO) - DIE VISITATION VON BISCHOF JAN SZEMBEK (1714-1718)
}

\begin{abstract}
Zusammenfassung
Das präsentierte Repertorium umfasst die Protokolle der in den Jahren 1714-1718 von Bischof Krzysztof Jan Szembek und seinen Delegierten durchgefüherten Visitationen der Diözese Culm (Chełmno). Diese Visitationsakten werden im Erzdiösenanarchiv in Lublin in zwei Volumina aufbewahrt (Sign. Rep60 A 152 und Rep60 A 153) und gehören zu den reichhaltigsten und inhaltlich interessantesten Visitationen dieser Diözese in altpolnischer Zeit. Am wertvollsten sind, neben der Schilderung des Zustandes der Diözese zu Beginn des 18. Jahrhunderts, die Eintragungen vieler Stiftungs- und Erektionsdokumente. Das Repertorium enthält die Regesten aller vor 1600 ausgestellter Dokumente. Vom methodologischen Standpunkt aus ist diese Publikation die Fortsetzung des früher veröffentlichten Repertoriums der Visitationen der Diözese Culm (Chełmno) aus dem 17. Jahrhundert.
\end{abstract}

